\title{
Moving-Bed, Granular-Bed Filter Development Program Option IIl: Development of Moving-Bed Filter Technology for Multi-Contaminant Control Task 14: Test Plan
}

\section{Topical Report}

J. C. Haas

K. B. Wilson

November 1994

Work Performed Under Contract No.: DE-AC2 1-90MC27423

For

U.S. Department of Energy

Office of Fossil Energy

Morgantown Energy Technology Center

Morgantown, West Virginia

By

Combustion Power Company

Menlo Park

Oakland, California 


\section{DISCLAIMER}

This report was prepared as an account of work sponsored by an agency of the United States Government. Neither the United States Government nor any agency thereof, nor any of their employees, makes any warranty, express or implied, or assumes any legal liability or responsibility for the accuracy, completeness, or usefulness of any information, apparatus, product, or process disclosed, or represents that its use would not infringe privately owned rights. Reference herein to any specific commercial product, process, or service by trade name, trademark, manufacturer, or otherwise does not necessarily constitute or imply its endorsement, recommendation, or favoring by the United States Government or any agency thereof. The views and opinions of authors expressed herein do not necessarily state or reflect those of the United States Government or any agency thereof.

This report has been reproduced directly from the best available copy.

Available to DOE and DOE contractors from the Office of Scientific and Technical Information, 175 Oak Ridge Turnpike, Oak Ridge, TN 37831; prices available at (615) 576-8401.

Available to the public from the National Technical Information Service, U.S. Department of Commerce, 5285 Port Royal Road, Springfield, VA 22161; phone orders accepted at (703) $487-4650$. 


\section{DISCLAIMER}

Portions of this document may be illegible in electronic image products. Images are produced from the best available original document. 
Moving-Bed, Granular-Bed Filter Development Program

Option III: Development of Moving-Bed Filter

Technology for Multi-Contaminant Control

Task 14: Test Plan

\title{
Topical Report
}

\author{
1. C. Haas \\ K. B. Wilson
}

Work Performed Under Contract No.: DE-AC21-90MC27423

\author{
For \\ U.S. Department of Energy \\ Office of Fossil Energy \\ Morgantown Energy Technology Center \\ P.O. Box 880 \\ Morgantown, West Virginia 26507-0880 \\ By \\ Combustion Power Company \\ Menlo Park \\ 2101 Webster Street, No. 1700 \\ Oakland, California 94612
}

November 1994 


\section{TABLE OF CONTENTS}

Page

1.0 APPROACH FOR MULTI-CONTAMINANT CONTROL IN A MOVING GRANULAR BED FILTER

2.0 REVIEW OF POTENTIAL SORBENTS

2.1 Clay for the Control of Alkali 3

2.2 Sodium Compounds for the Control of Halogens 4

2.3 Nickel Catalyst for the Dehydrogenation of Ammonia 5

2.4 Clay or Sodium Sorbents for Control of Selected Trace Metals 6

3.0 TEST PLAN FOR THE DEVELOPMENT OF CLAY SORBENTS 8

3.1 Screening of Clay Sorbents 8

3.1.1 Thermal Analysis Evaluation of Five Clay Sorbents 8

3.1.2 Evaluation of Two Selected Clays for Alkali Sorption 9

3.2 Binders and Pelletization Technique Evaluation 11

3.2.1 Binders 11

3.2.2 Pelletization Techniques 12

3.2.3 Evaluations 12

3.3 Evaluation of Preferred Formulation of Alkali Sorbent 13

3.3.1 Pellet Production 13

3.3.2 Chemical Reactivity and Kinetics 13

3.3.3 Physical Properties 15

3.4. Engineering Reactor Model for Alkali Sorption 16

3.5 Evaluation of Clay Sorbent for Sorption of Trace Metals 16

3.5.1 Pellet Production 16

$\begin{array}{ll}\text { 3.5.2 Sorbent Saturation Capacity } & 17\end{array}$

3.5.3 Chemical Reactivity and kinetics of Sorption of Trace Metals 17

3.5.4 Strength Characteristics of Reacted Pellets 17

3.5.5 Engineering Reactor Model for Metal Sorption 18

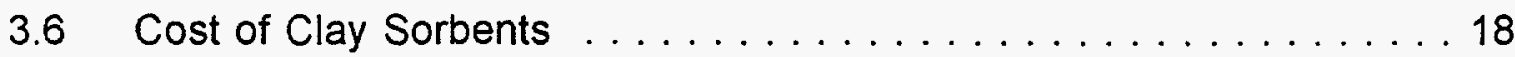


4.0 TEST PLAN FOR DEVELOPMENT OF SODIUM-BASED SORBENTS FOR THE CONTROL OF HALOGENS AND METALLOIDS USING A GBF 21

4.1 Review Results from Current DOE Program 21

4.2 Preparation of Sorbent 21

4.3 Chemical Reactivity of Sorbent

4.4 Physical Properties of Sorbent 21

4.5 Engineering Reactor Model for Halogen Sorbent 22

4.6 Fabrication Cost Evaluation 22

4.7 Trace Metalloid Sorption $\quad 22$

5.0 TEST PLAN FOR EVALUATION OF AMMONIA DECOMPOSITION CATALYSTA

5.1 Acquisition of Catalyst 24

5.2 Confirmation of Catalyst Reactivity 24

5.3 Mechanical Integrity of Ammonia Decomposition Catalyst 25

5.3.1 Crush Strength 25

5.3.2 ASTM Attrition Test 25

5.3.3 Special Attrition Test 25

$\begin{array}{ll}5.4 & \text { Engineering Model }\end{array}$

$\begin{array}{lll}6.0 & \text { TEST APPARATUS } & 26\end{array}$

6.1 Thermal Analysis 26

6.2 Pellet Preparation Equipment 27

6.3 Double TGA Apparatus for Measurement of Clay Reactivity 29

6.4 Fixed Bed Reactor for Integral Tests of Clay Reactivity 29

6.5 Lift Pipe Attrition Apparatus 32

6.6 Apparatus for Determining Reactivity of Sorbents for Halogens and Metalloids $\quad 34$

6.7 Apparatus for Determining Ammonia Catalyst Reactivity 35

7.0 EVALUATION OF MULTI-CONTAMINANT CONTROL SORBENT IN FIELD TRIALS

$\begin{array}{lll}8.0 & \text { Schedule } & 36\end{array}$

$\begin{array}{lll}9.0 & \text { References } & 42\end{array}$ 


\section{LIST OF FIGURES}

Figure

Page

1 Schematic Diagram of Balling Pan Load

Double TGA Apparatus for Clay Sorbent Reactivity Studies

Integral Fixed Bed Test Apparatus for Measuring Clay Reactivity

Moving lift pipe/ moving bed attrition apparatus

33

5 Apparatus for Measurement of Halogen and Metalloid Reactivity

6 Apparatus for Determining Reactivity of Ammonia Catalyst

\section{LIST OF TABLES}

Table

Page

1 Control of Coal Contaminants 2

2 Metal Chlorides Which Could be Used in Screening Tests 9

3 Conditions for TGA Reactivity Screening Tests 11

4 Test Conditions for TGA Binder Evaluations 13

5 Test Conditions for Sodium Saturation Capacity Tests 14

$6 \quad$ Integral Reactor Tests for Alkali Sorption 15

$7 \quad$ Test Conditions for Sorbent Saturation With Trace Metal 17

8 Integral Reactor Tests for Trace Metal Sorption 18

9 Summary of Tests and Analysis for Clay Sorbent 19

10 Summary of Tests for Evaluation of Sodium-Based Sorbents 23

11 Screening Test For Ammonia Decomposition 26 


\subsection{APPROACH FOR MULTI-CONTAMINANT IN A MOVING GRANULAR BED FILTER}

Combustion Power Company's granular bed filter (GBF) has demonstrated the ability to remove particulates from high-pressure and high-temperature coal gas streams (Wilson, 1989). This is accomplished by the impaction and capture of ash particle on the filter medium. The filter media used in the demonstration tests were $2 \mathrm{~mm}$ and $3 \mathrm{~mm}$ mullite spheres, which are believed to be chemically inert with respect to the constituents in coal gases. In scale-up studies of the GBF (Wilson, 1993), the size of the filter medium changed to a nominal $1 / 4^{\prime \prime}$ diameter to increase the capacity of the filter. The new filter medium is a dense ceramic material which is probably inert with respect to the coal gas constituents. For the control of particulates and other contaminants, we propose to replace the inert filter medium with a filter medium which is either chemically or catalytically reactive with respect to selected constituents in the gas stream. A chemically reactive filter medium will have a finite life and will need to be replaced on a periodic basis, most likely during a scheduled plant outage. Alternatively, the filter medium could be replaced on line by the introduction of fresh filter medium in place of spent filter medium should the life of the chemically reactive filter medium not be compatible with a normal outage sequence. The objective of this test program is to develop and evaluate filter media which are both chemically reactive and have the structural properties required of a GBF filter medium.

The test program will develop and evaluate potential filter materials which have been demonstrated to be reactive to contaminants in coal gas streams in either gasification or combustion environments. Table 1 presents a prioritized list of contaminants which we believe may be controlled with a GBF using specialized filter media. As shown in Table 1 , four types of sorbents which could be developed are:

- A clay-based filter medium for the control of alkali and some heavy metals in either reducing or oxidizing gas environments

- A sodium-based filter medium for the control of halogens and some heavy metals in reducing gas environments

- A nickel catalyst for the destruction of $\mathrm{NH}_{3}$ and $\mathrm{HCN}$ in a reducing gas environment

- A silica-based sorbent for the control of cesium and lead

We would like to investigate all of the above possible GBF filter media; but at this time, we propose to investigate the control of sodium in gasification and combustion gas streams. As Option 1 to the base program of alkali control, we would evaluate the clay media developed for alkali control for the additional control of selected trace metals. Option 2 is the control of halogens and selected metalloids using sodium based sorbents 
Table 1

Control of Coal Contaminants

\begin{tabular}{cllll}
\hline Priority & Gas Environment & Contaminants & Temperature & Sorbent/Catalysts \\
\hline 1 & Reducing & Alkali & $800-1000^{\circ} \mathrm{C}$ & Alumina Silicates \\
2 & Reducing & Halogens & $425-650^{\circ} \mathrm{C}$ & $\begin{array}{l}\text { Sodium Compounds } \\
\text { i.e., } \mathrm{NaHCO}_{3} \\
\text { Alumina Silicates }\end{array}$ \\
3 & Oxidizing & Alkali & $800-1000^{\circ} \mathrm{C}$ & Nickel Catalysts \\
4 & Reducing & $\mathrm{NH}_{3}, \mathrm{HCN}$ & $800-950^{\circ} \mathrm{C}$ & \\
5 & Reducing & $\mathrm{As}, \mathrm{Sb}, \mathrm{Se}$ & $450-650^{\circ} \mathrm{C}$ & Sodium Compounds \\
6 & Oxidizing & $\mathrm{Cd}, \mathrm{Pb}$ & $800-1000^{\circ} \mathrm{C}$ & Alumina Silicates \\
7 & $\mathrm{Ba}, \mathrm{Be}, \mathrm{Cr}$ & & Alumina Silicates \\
& Reducing & $\mathrm{Cd}, \mathrm{Pb}$ & $800-1000^{\circ} \mathrm{C}$ & Silica \\
\hline
\end{tabular}


and Option 3 is the control of ammonia using catalysts. The development of silica based sorbents for $\mathrm{Cs}$ and $\mathrm{Pb}$ control would be left for a future time.

\subsection{REVIEW OF POTENTIAL SORBENTS}

In this section we present justification for the choice of contaminants to be controlled and the proposed method of control.

\subsection{Clay for the Control of Alkali}

The presence of alkali species in PFBC or IGCC gas streams is of concern because of the potential corrosion which alkali species can cause in a gas turbine. Also, alkali species are associated with low melting compounds which can provide the "glue" for forming deposits on turbine and heat exchanger surfaces. For these reasons, turbine manufacturers have placed restrictions on the amount of alkali (sodium and potassium) that can enter a gas turbine. The acceptable levels of alkali in the fuel gas stream entering the turbine combustor range from 50 to 200 ppbw depending on the gas temperature and the turbine manufacturer (Tamhankar and Wen, 1981). More recent studies are more stringent, giving the permissible inlet concentration to the turbine itself as 24 ppbw (Bossart et al., 1990; Lee and Myles, 1987). These levels are below the expected alkali levels in coal process streams (Zakkay et al., 1985; Ciliberti and Lippert, 1986; Krishnan et al., 1990, Lee et al., 1993), indicating the need for alkali control.

Several investigators have reported successful alkali removal from high-temperature gas streams with sorbents of activated bauxite, attapulgus clay, calcium montmorillonite clay, diatomaceous earth, kaolin clay, and emathlite clay. Activated bauxite and diatomaceous earth have been reported to effectively capture $\mathrm{NaCl}, \mathrm{KCl}$, and $\mathrm{K}_{2} \mathrm{SO}_{4}$ (Lee and Johnson, 1980). One set of sorbent screening experiments found diatomaceous earth, attapulgus clay, and activated bauxite to be the most effective for removal of alkali (Jain and Young, 1985).

Emathlite, a type of fullers earth, was found to be a leading getter of alkali (Bachovchin et al., 1986). The clay had a high capacity for sodium and binds the sodium irreversibly. At extreme conversions, the clay was found to become sticky. This could be a problem for GBF operation but is unlikely to occur as these extreme conversions are not realistically obtained. Kaolin, bauxite, and emathlite were all found to be capable of removing alkali from coal conversion streams (Uberoi et al., 1990). Kaolin and emathlite adsorption of alkali was an irreversible process. The maximum sorption capacity of the kaolin was about $25 \%$, while that of bauxite and emathlite was about $15 \%$. Screening of alkali sorbents (McLaughlin, 1990) found activated bauxite, calcium montmorillonite clay, attapulgus clay, zeolite ZSM-5, emathlite clay, kaolin clay and diatomacious earth to be alkali getters. Kaolin, emathlite and calcium montmorillonite clays all performed equally well. Calcium montmorillonite was chosen for further investigation because of its local availability and because it produced the strongest pellets. 
Of these alkali sorbents tested, bauxite was reported to be fractionally irreversible with alkali removal being $10 \%$ chemical sorption and $90 \%$ physically absorbed as watersoluble alkali (Lee and Johnson, 1980) while the clay sorbents react irreversibly with alkali (Bachovchin, 1986; Uberoi, 1990; McLaughlin, 1990). Activated bauxite is a relatively expensive sorbent which would not be suitable as a non-regenerable sorbent.

The reaction of alkali with clay is thought to proceed by the reaction (McLaughlin, 1990):

$$
2 \mathrm{MCl}_{(\mathrm{g})}+\mathrm{H}_{2} \mathrm{O}_{(\mathrm{g})}+\mathrm{Al}_{2} \mathrm{O}_{3} \circ \times \mathrm{SiO}_{2(\mathrm{~s})} \rightarrow \mathrm{M}_{2} \mathrm{OAl}_{2} \mathrm{O}_{3} \circ \times \mathrm{SiO}_{2(\mathrm{~s})}+2 \mathrm{HCl}_{(\mathrm{g})}
$$

where $\mathrm{M}$ is a metal $\mathrm{K}$ or $\mathrm{Na}$.

Bachovchin et al. (1986) developed a model of a fixed bed reactor using cylindrical pellets of emathlite, a calcium montmorillonite clay mined in Florida, for the removal of alkali from coal gasification streams. We adapted the model to a spherical pellet geometry and to a circulating bed as used in a GBF. The predicted sorbent life, using the rate expression for emathlite, would be 7400 hours for a $20 \mathrm{ft}$ deep bed. The sorbent would contain $17.3 \% \mathrm{Na}$ at the end of its life. The inlet sodium concentration used in the model is 10 ppmv and the outlet is $20 \mathrm{ppbv}$. A lower bed depth corresponds to a shorter sorbent life and lower sorbent utilization. A fixed bed reactor having a similar bed depth would have a life of 8400 hours and an average Na pick up of $19.7 \%$. This existing model will be used in the analysis of data collected in the proposed tests.

\subsection{Sodium Compounds for the Control of Halogens}

Emissions of chlorine from a coal-fired power plant can range from $50 \mathrm{ppmv}$ to several thousand ppmv, depending on the chlorine content of the coal and the coal processing technique (Sloss, 1992). Coal from Kentucky, Illinois, Ohio, Oklahoma, Pennsylvania, and West Virginia typically have high chlorine contents of several thousand ppm. A medium Btu gas derived from high-chlorine Illinois coal can have an $\mathrm{HCl}$ content as high as 1500 ppmv (O'Brien et al., 1992). The presence of chlorine in a coal gas stream can cause acidic corrosion of downstream equipment such as turbine blades and heat exchangers. It can act as a poison of molten carbonate fuel cells electrodes. Beside having an adverse effect on equipment, the emission of $\mathrm{HCl}$ into the atmosphere can have deleterious effects. The 1990 Clean Air Amendments Bill requires that the $\mathrm{HCl}$ limit be reduced to 10 ton/yr.

Sodium minerals containing sodium bicarbonate or sodium carbonate react with $\mathrm{HCl}$, forming $\mathrm{NaCl}, \mathrm{CO}_{2}$ and $\mathrm{H}_{2} \mathrm{O}$. Researchers at Physical Science Inc. evaluated shortite $\left(\mathrm{NaCO}_{3} \cdot 2 \mathrm{CaCO}_{3}\right)$ and trona $\left(\mathrm{NaCO}_{3} \cdot \mathrm{NaHCO}_{3}\right)$ as sorbents for the removal of $\mathrm{HCl}$ vapors (Ham et al., 1984). Shortite had a higher reactivity than trona. Laboratory and benchscale experiments at SRI International evaluated naholite $\left(\mathrm{NaHCO}_{3}\right)$, shortite and dawsonite $\left(\mathrm{NaAl}(\mathrm{OH})_{2} \mathrm{CO}_{3}\right.$ for the removal of $\mathrm{HCl}$ from simulated coal gas (Krishnan et al., 1986). All the tested sorbents reduced $\mathrm{HCl}$ concentration from $300 \mathrm{ppmv}$ to $1 \mathrm{ppmv}$. 
Nahcolite had a superior sorption capacity with the spent sorbent containing as much as 54 wt\% chloride. Gas impurities such as $\mathrm{H}_{2} \mathrm{~S}$ and trace metals did not effect the rate of $\mathrm{HCl}$ removal. An economic evaluation of the cost of removal of $\mathrm{HCl}$ using a nahcolite sorbent showed the cost of electricity would increase 2 mils $/ \mathrm{kWh}$. Capital investment and the capital recovery were the major cost components, whereas the cost of the nahcolite sorbent had only a small impact. This suggests that using a GBF as the reactor vessel would significantly reduce the cost of an $\mathrm{HCl}$ removal process.

Based on these encouraging results, SRI International was awarded a follow-up contract by METC to investigate different processes for the fabrication of sorbents for the removal of $\mathrm{HCl}$ vapor from hot, coal-derived fuel gas streams (Krishnan et al., 1994). The program, which is scheduled for completion in Sept. of 1995, is investigating formulation of sodium sorbents for use in fixed-, moving-, and fluidized-bed reactors. RTI is collaborating with SRI on the development of the sodium sorbents and will develop equipment and expertise which will be beneficial in a program to develop sodium sorbents for use in a GBF.

\subsection{Nickel Catalyst for the Dehydrogenation of Ammonia}

Coal is typically composed of $1-2 \%$ organic nitrogen which is converted into ammonia, hydrogen cyanide, and nitrogen during the carbonization or gasification of coal. The extent of ammonia formation depends on coal properties and the processing conditions. High-temperature gasification such as a Texaco oxygen blown gasifier produces about 2000 ppmv of ammonia, while lower temperature gasification such as an air-blown Lurgi or GE gasifier produces concentrations of about 5000 ppmv (Jothimurugesan et al., 1993). If unabated, the ammonia can be converted into high levels of oxides of nitrogen in the turbine combustor.

The equilibrium concentration of ammonia in a fuel gas stream depends on the gas composition, temperature and pressure. For the GE air-blown gasifier, the ammonia concentration increases with pressure and decreases with temperature after having reached a peak at about $625^{\circ} \mathrm{C}$. At 10 atm and $625^{\circ} \mathrm{C}$, the equilibrium concentration is $300 \mathrm{ppmv}$ and at $850^{\circ} \mathrm{C}$ and $10 \mathrm{~atm}$ it is $140 \mathrm{ppmv}$ (Krishnan et al., 1988). The thermal decomposition of ammonia to its equilibrium value is slow due to the high activation energy of $>92 \mathrm{kcal} / \mathrm{mole}$ for the equilibrium reaction (Krishnan et al., 1987). Catalyst which reduce the high activation energy can be used to achieve the equilibrium concentration.

Krishnan et al. (1988) found that a commercial catalyst, HTSR-1 manufactured by Haldor Topsoe AVS, Copenhagen, effectively decomposed ammonia in simulated coal fuel gas streams. The catalyst is nickel supported on a magnesium aluminate substrate. Catalysts have the potential of being poisoned by the presence of gas impurities such as $\mathrm{H}_{2} \mathrm{~S}, \mathrm{HCl}$ and tars. HTSR -1 operating at $850^{\circ} \mathrm{C}$ achieved $99 \%$ conversion of 5000 ppmv of ammonia in the presence of $2000 \mathrm{ppmv}$ of $\mathrm{H}_{2} \mathrm{~S}$. At lower temperatures, $650^{\circ} \mathrm{C}$, the 
catalyst completely deactivated in the presence of $10 \mathrm{ppmv}$ of $\mathrm{H}_{2} \mathrm{~S} . \mathrm{HCl}$ had no adverse affects on catalyst activity. Simulated coal tar was cracked by the catalyst into $\mathrm{CO}$ and $\mathrm{H}_{2}$.

Lappälahti et al. (1991) investigated the catalytic decomposition of ammonia in fuel gas produced by peat gasification. The potential catalyst investigated were iron sinter, iron pellet, ferrous dolomite, dolomite, limestone and as reference materials inert silicon carbide and commercial nickel catalyst. The ferrous materials and the nickel catalyst were the most effective materials for decomposing ammonia. The large quantity of tar produced by the gasifier did not adversely affect ammonia decomposition by the catalytically active materials. The effect of $\mathrm{H}_{2} \mathrm{~S}$ on catalytic activity was not evaluated since very little sulfur was present in the peat.

Gangwal et al. (1994) began investigating the use of ammonia decomposition catalyst in conjunction with the $\mathrm{H}_{2} \mathrm{~S}$ sorbent zinc titanate. At temperatures below $800^{\circ} \mathrm{C}$, none of the catalyst investigated were effective in a high $-\mathrm{H}_{2} \mathrm{~S}$ environment. The direction of the program has changed to determining the life of ammonia decomposition catalyst operating at temperatures above $800^{\circ} \mathrm{C}$ in a high- $\mathrm{H}_{2} \mathrm{~S}$ environment (Gupta, 1994). It is expected that this work will provide a foundation for the proposed tests to develop ammonia catalyst for use in a GBF.

\subsection{Clay or Sodium Sorbents for Control of Selected Trace Metals}

The fate of trace elements from advance power cycles is currently being investigated in several DOE programs. Measurements are being conducted at American Electric Power's PFBC Tidd plant to determine the emissions of hazardous air pollutants (HAPS) (Mudd et al., 1994). Similar measurements are being conducted at Destec's Louisiana Gasification Technology Inc. IGCC plant (Eklund et al., 1994). The results of these programs will help determine the need for control of trace elements from advance coalfired power systems. Mojtahedi et al. (1990) measured trace element emissions from a pilot-scale PFBC. A small proportion of the trace elements measured left the combustor as vapors, $7.5-16.0 \%$ of the initial mercury, about $5 \%$ of the initial cadmium, up to $4 \%$ of the initial arsenic, $1-3 \%$ of the initial lead and $0.5-1.2 \%$ of the initial copper.

Energy Research Corporation (Pigeaud et al., 1994) is investigating the fate of trace elements in gasification processes. It ranked trace emissions in terms of abundance, volatility and toxicity, determining that $\mathrm{As}, \mathrm{Se}, \mathrm{Sb}, \mathrm{Zn}$ and $\mathrm{Pb}$ are the most significant trace elements to be studied. It also recommended the study of the removal of cadmium, chlorine and mercury.

Investigators in Espoo, Finland used a fixed bed of granular sorbents to remove trace metals from simulated hot combustion gas streams. Sorbents evaluated were coarse limestone, slag, dolomite and $\mathrm{Al}_{2} \mathrm{O}_{3}$. The removal of lead and zinc chlorides was significantly enhanced by the presence of water vapor and $\mathrm{SO}_{2}$ in the carrier gas. The 
investigators concluded that a fixed bed of suitable solid sorbent particles can effectively remove trace quantities of undesirable elements from large gas volumes.

Uberoi et al. (1991a, b) evaluated sorbents for the sorption of $\mathrm{CdCl}_{2}$. Sorbents were evaluated in a simulated flue gas at $800^{\circ} \mathrm{C}$. Bauxite and to a lesser extent kaolin clay were effective sorbents for cadmium. The products of cadmium sorption with bauxite were more water soluble than those formed with kaolinite. A thin flake of bauxite increased its weight by $30 \%$ as compared to a flake of kaolinite, which had an $18 \%$ increase in weight from the sorption of cadmium.

Uberoi (1990) evaluated the sorption of lead chloride by silica, alumina, kaolinite, bauxite, emathlite and lime. Most of the lead captured by kaolinite and silica was water insoluble, while most of the lead captured was water soluble for the other sorbents. Kinetic rate studies determined that kaolinite increased its weight by $92 \%$ and bauxite had a $41 \%$ weight gain.

Crosley (1994) proposed a method for determining the likely reactivity between trace metals and potential sorbents. If the potential sorbent and the trace metal form solutions or mixtures according to phase diagrams, then it is likely that the potential sorbent will be reactive with respect to the trace metal. By consulting the phase diagrams published by the American Ceramic Society, he determined that alumina silicates are likely sorbents for barium, beryllium, chrome, lead, cobalt, strontium and uranium. Silica was also a likely sorbent for all of the above elements as well as cesium and strontium.

SRI's investigation of sodium sorbents for the removal of halogens found that in addition to $\mathrm{HCl}$ removal, several of the sodium sorbents also removed some trace metalloids (Krishnan et al., 1986). Nahcolite removed $27 \%$ of the antimony vapor and up to $17 \%$ of the selenium vapor. Dawsonite removed $100 \%$ of the arsenic vapor and shortite removed $15 \%$ of the arsenic vapor. 


\subsection{TEST PLAN FOR THE DEVELOPMENT OF CLAY SORBENTS}

\subsection{Screening of Clay Sorbents}

The purpose of the clay screening tests is to evaluate the relative reactivity of candidate clays for the sorption of selected metal compounds. The clays will be evaluated in gasification and pressurized fluidized bed combustion (PFBC) gas environments. Claybased filter material has the potential to control the following metals: sodium (Uberoi, 1991b), lead (Uberoi,1990), cadmium (Uberoi, 1991a), barium (Crosley, 1994), beryllium (Crosley, 1994) and chrome (Crosley, 1994). Five candidate clays have been identified as having potential for removing alkali and other metals from high-temperature coal gas streams. These clays are:

- Emathlite (Bachovchin, 1986)

- Kaolin (Uberoi,1990)

- Bauxitic kaolin

- $\quad$ Attapulgite (McLaughlin, 1990)

- Calcium montmorillonite (McLaughlin,1990)

The chemical composition of each clay will be determined. A loss on ignition analysis will be performed on each clay as part of the chemical analysis. The elemental composition will be reported as oxides.

\subsubsection{Thermal Analysis Evaluation of Five Clay Sorbents}

McLaughlin (1990) developed a simple screening test which he used to evaluate the relative effectiveness of clays for sorption of sodium vapors. The method can easily be extended to the evaluation of clay sorbents for the sorption of other metals. Samples of the clay sorbent and the metal chloride are ground so that all of the samples to be evaluated are minus a 325 mesh screen. The sample clays are than calcined in muffle furnace to $850^{\circ} \mathrm{C}$ for $12-24$ hours and cooled in a desiccator and re-ground and sized. The prepared clay is mixed with one of the metal chlorides listed in Table 2,10\% by weight metal chloride. The mixture is evaluated in a thermal analyzer which combines thermal gravimetric analysis (TGA) and differential thermal analysis (DTA). The TGA output shows the weight loss of the sample as a function of temperature and the DTA shows the difference in temperature between the sample and an inert reference material heated with the sample. This difference in temperature is caused by endothermic and exothermic reactions occurring in the sample. The clay mixture which has the lowest weight loss would have absorbed and reacted with the largest quantity of metal vapor.

Each of the five clays and a known non-getter will be run with sodium chloride. 
The runs will use a simulated gasification stream composed of $90 \% \mathrm{CO}_{2}$ and $10 \%$ $\mathrm{H}_{2}$. By means of the water gas shift reaction, the gas mixture will equilibrate at temperature, producing a mixture of $\mathrm{H}_{2}, \mathrm{H}_{2} \mathrm{O}, \mathrm{CO}_{2}$ and $\mathrm{CO}$. The water vapor or hydrogen reacts with the chlorine in the metal chloride producing $\mathrm{HCl}$, allowing the metal oxide or hydroxide to react with the clay. The thermal analyses will be set up to run with a heating rate of $15^{\circ} \mathrm{C}$ per minute to a maximum temperature of $1000^{\circ} \mathrm{C}$, a gas flow rate of $50 \mathrm{ml} / \mathrm{min}$, and a sample weight of $20 \mathrm{mg}$. Each clay will also run with sodium chloride in a combustion type carrier gas consisting of $7 \%$ $\mathrm{CO}_{2}, 3 \% \mathrm{H}_{2} \mathrm{O}, 78 \% \mathrm{~N}_{2}$, and $12 \% \mathrm{O}_{2}$. Three of the clays will be chosen for evaluation with the trace metals of $\mathrm{Pb}, \mathrm{Cd}$ and $\mathrm{Cr}$ in a reducing gas environment. A total of 20 thermal analyses will be run.

Two types of clay will be chosen for further evaluation. The selection process will be based on the reactivity of each clay with sodium chloride, with each of the other metal chlorides and the relative cost of the each of the clays.

Table 2

Metal Chlorides Which Could be Used in Screening Tests

\begin{tabular}{lll}
\hline & & \\
$\mathrm{NaCl}_{\mathrm{PbCl}}$ & 801 & 1413 \\
$\mathrm{CdCl}_{2}$ & 501 & 950 \\
$\mathrm{BaCl}_{2}$ & 568 & 960 \\
$\mathrm{BeCl}_{2}$ & 962 & 1560 \\
$\mathrm{CrCl}_{2}$ & 440 & 520 \\
\hline
\end{tabular}

\subsubsection{Evaluation of Two Selected Clays for Alkali Sorption}

The objective of these tests is to determine which of the two selected clays has the characteristics which would make it more suitable as a alkali sorbent in a GBF environment. Each clay will be evaluated in terms of pellet strength and chemical reactivity.

\section{Clay Preparation}

Each of the two clays to be further evaluated will be dried, screened and ground if necessary. The pellets will be made from minus 325 mesh material. Approximately a kilogram of each clay should be prepared. 


\section{Production of Pellets}

Three $\mathrm{mm}$ and seven $\mathrm{mm}$ diameter round balls will be produced by an extrusion process followed by rounding. The pellets are to be extruded at a moisture content which produces pellets with maximum green strength. The moisture content at maximum green strength will be determined by trial and error. One hundred fifty grams of $3 \mathrm{~mm}$ and $7 \mathrm{~mm}$ pellets from each of the two clays are to be made without the use of binders, cured in air at room temperature for 3 days and then stored in airtight containers.

\section{Evaluation of Pellets}

Based on the results of the following four tests, one type of clay will be chosen for further evaluation as an alkali sorbent. Test will be preformed on both $3 \mathrm{~mm}$ and $7 \mathrm{~mm}$ spherical pellets. It is expected that $7 \mathrm{~mm}$ diameter pellets will prove to be adequate for further development since this is the current size of the filter medium used in the GBF. Three $\mathrm{mm}$ pellets have been included in the screening tests to insure that the larger pellet size does not significantly effect sorbent reactivity.

a. Green Strength The green strength, as determined by drop tests, of the freshly made pellets will be measured for each type of clay pellet.

b. Crush Strength The crush strength of air-cured pellets, pellets calcined at $1,500^{\circ} \mathrm{F}$ for 4 hours, and pellets which have been reacted in the TGA tests will be measured for each type of clay.

c. Attrition Resistance The attrition resistance of each type of calcined pellet will be measured using ASTM D4058-92.

d. Chemical Reactivity The chemical reactivity of each type and size of pellet will be determined from TGA tests by comparing the rate of adsorption of sodium and percent weight gain. Test conditions are given in Table 3 . The reacted pellets will be analyzed for total sodium (by weight) and water soluble sodium. 
Table 3

Conditions for TGA Reactivity Screening Tests

Test Parameter

Gas Composition

Gas Temperature

$\mathrm{NaCl}$ Concentration

Pressure

Space Velocity

Test Duration

Pellet Size

Number of Tests

Minimum No. of Pellets Per Test 3
Value

$90 \% \mathrm{CO}_{2}, 10 \% \mathrm{H}_{2}$

$870^{\circ} \mathrm{C}$

$40 \mathrm{ppmv}$

$1 \mathrm{~atm}$.

$100,000 / \mathrm{hr}$

24 hours

$3 \mathrm{~mm} \& 7 \mathrm{~mm}$

4

\subsection{Binders and Pelletization Technique Evaluation}

The purpose of these evaluations is to determine the effect of pelletization technique and binders on pellet strength and reactivity using the clay selected from the screening tests. Two pelletization techniques will be evaluated. The first is disk pelletization, which is the less costly of the two procedures. The other technique is extrusion followed by rounding which will have already been used in the preparation of pellets for the screening tests. The selected clay should be dried and screened such that 16 kilograms of $90 \%$ minus 325 mesh material is available for evaluation. It is more than likely that the clay will come from the vendor in this condition.

After completing the experimental work to determine the best fabrication method for the clay pellets, a cost estimate will be made for providing $150-300 \mathrm{ft}^{3}$ of pellets for pilot plant tests at DOE's Power System Development Facility.

\subsubsection{Binders}

The following binders will be evaluated:

- Water at optimum moisture content

- Water at optimum moisture content and $5 \%$ sodium bentonite by dry weight 
- Water at optimum moisture content and $10 \%$ sodium bentonite by dry weight

- Water at optimum moisture content and $10 \%$ Portland cement by dry weight

- Water at optimum moisture content and $2 \%$ sodium silicate by dry weight

\subsubsection{Pelletization Techniques}

Using the disk pelletizer, $150 \mathrm{~g}$ of $7 \mathrm{~mm}$ diameter balls will be prepared using each of the above binders. Similarly, $150 \mathrm{~g}$ of $7 \mathrm{~mm}$ diameter balls will be prepared using the extrusion process followed by rounding for each of the selected binders. A total of 10 preparations will be prepared. After pelletization the pellets will be allowed to air dry at room temperature for 3 days except for the pellets with Portland cement, which will be cured at $80 \%$ to $100 \%$ relative humidity for 7 days. The pellets with Portland cement should not be wetted by condensate during the curing process.

\subsubsection{Evaluations}

The following evaluation techniques will be used to select the best pelletization process and binder to produce an alkali sorbent for use in a GBF.

a. Green Strength The green strength of the freshly made pellets will be measured for each pelletization technique using only water as a binder. The binders are expected to have minimal effect on pellet green strength.

b. Crush Strength The crush strength of air-cured pellets, pellets calcined at $1,500^{\circ} \mathrm{F}$ for 4 hours, and pellets which have been reacted in the TGA tests will be measured for each type of binder and each pelletization technique.

c. Attrition Resistance The attrition resistance of each type of calcined pellet will be measured using ASTM D4058-92.

d. Chemical Reactivity The chemical reactivity of each type of pellet will be determined from TGA tests comparing the sorption of sodium. Test conditions are given in Table 4. 


\section{Test Conditions for TGA Binder Evaluations}

Test Parameter

Gas Composition

Gas Temperature

$\mathrm{NaCl}$ Concentration

Pressure

Space Velocity

Test Duration

Number of Tests

Minimum No. of Pellets Per Test 3
Value
$90 \% \mathrm{CO}_{2}, 10 \% \mathrm{H}_{2}$

$870^{\circ} \mathrm{C}$

$40 \mathrm{ppmv}$

$1 \mathrm{~atm}$.

$100,000 / \mathrm{hr}$

24 hours

10

\subsection{Evaluation of Preferred Formulation of Alkali Sorbent}

\subsubsection{Pellet Production}

One hundred and fifty $\mathrm{g}$ of pellets will be produced by the preferred technique and curing processes determined in Section 3.2. The pellet diameter will be $7 \pm 1 \mathrm{~mm}$. In addition to the $7 \mathrm{~mm}$ pellets, $150 \mathrm{~g}$ of $3 \mathrm{~mm}$ pellets will also be prepared with the preferred technique. The $3 \mathrm{~mm}$ and $7 \mathrm{~mm}$ pellets will be used in the saturation tests, Section 3.3.2, to insure that there is not a significant difference in reactivity between the $3 \mathrm{~mm}$ and $7 \mathrm{~mm}$ pellets. After verification of reactivity by means of the saturation capacity test, $30 \mathrm{~kg}$ of $7 \mathrm{~mm}$ pellets will be produced and cured. Fifteen $\mathrm{kg}$ of the pellets will be calcined at $870^{\circ} \mathrm{C}$ for four hours in preparation for the crush strength tests and the attrition tests. The other $15 \mathrm{~kg}$ of pellets will be used in the integral tests.

\subsubsection{Chemical Reactivity and Kinetics}

\section{Alkali Saturation Capacity}

The objective of these tests is to determine the maximum sorption of sodium by the clay pellets. TGA will be used to determine the sodium saturation capacity of the clay pellets. Table 5 gives the test conditions. One test will be conducted with no $\mathrm{HCl}$ addition and one will be run with $\mathrm{HCl}$ for each pellet size. $\mathrm{HCl}$ is known to inhibit the sorption of alkali with clay sorbents (McLaughlin,1990). The test 
duration will be such that the rate of adsorption at the end of the test is no more than $5 \%$ of the initial rate.

Table 5

Test Conditions for Sodium Saturation Capacity Tests

Test Parameter

Value

Gas Composition

Gas Temperature

$\mathrm{NaCl}$ Concentration

Pressure

Space Velocity

$\mathrm{HCl}$ Concentration

Pellet Size

Number of Tests

Minimum No. of Pellets Per Test 3

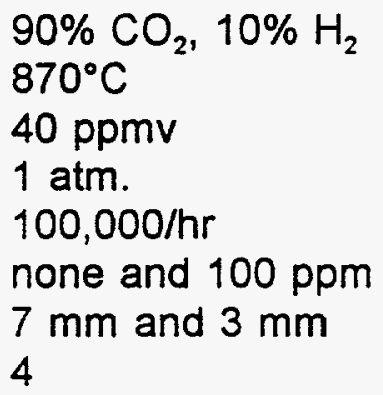

\section{Kinetic Studies}

Integral fixed-bed experiments will be run on a deep bed, $8 \mathrm{~cm}$ diameter by $30 \mathrm{~cm}$, with the preferred formulation. Four integral tests are planned and Table 6 shows the test conditions. The tests will evaluate the effects of gas composition and $\mathrm{HCl}$ concentration of the reaction kinetics. The test system is to deliver a gas stream at temperature with $40 \mathrm{ppm}$ concentration of $\mathrm{NaCl}$ to the integral reactor. The inlet concentration can be determined by periodic on-line sampling or through previous calibration with an on-line sampling device. The outlet concentration from the integral reactor will be measured with an on-line monitor. Because of the large quantity of sorbent in the reactor and the low inlet concentration, tests 1 to 3 will be run for 150 hours. It is not likely that breakthrough will occur in this time span. Test 4 will be run with an inlet concentration of $40 \mathrm{ppmv}$ and will be run until the outlet sodium concentration increases to $10 \mathrm{ppmv}$. After each test, the bed will be sectioned into 10 intervals and total sodium will be determined for each section of the bed. Water-soluble sodium will be determined for the top and bottom layers of the bed. A change in the relative amount of water soluble sodium could indicate a change in the sorption mechanism for different positions in the bed. 
Table 6

Integral Reactor Tests for Alkali Sorption

\begin{tabular}{|c|c|c|c|}
\hline Gas type & Temperature $\left({ }^{\circ} \mathrm{C}\right)$ & $\begin{array}{c}0 \text { ppmv } \\
\mathrm{HCl}\end{array}$ & $\begin{array}{c}100 \mathrm{ppmv} \\
\mathrm{HCl}\end{array}$ \\
\hline Reducing & 870 & Test \#1 & $\begin{array}{l}\text { Test \#2 } \\
\text { Test \#4 }\end{array}$ \\
\hline Combustion & 870 & Test \#3 & \\
\hline \multicolumn{2}{|c|}{$\begin{array}{l}\text { Reducing gas composition: } \\
\text { Combustion gas composition: } \\
\text { Space velocity: } \\
\text { Bed diameter: } \\
\text { Bed length: } \\
\text { Pellet diameter: } \\
\text { NaCl inlet concentration: } \\
\text { Test duration: }\end{array}$} & \multicolumn{2}{|c|}{$\begin{array}{l}90 \% \mathrm{CO}_{2}, 10 \% \mathrm{H}_{2} \\
95 \% \mathrm{~N}_{2}, 5 \% \mathrm{H}_{2} \mathrm{O} \\
1,000 / \mathrm{hr} \\
8 \mathrm{~cm} \\
30 \mathrm{~cm} \\
7 \mathrm{~mm} \\
40 \mathrm{ppmv} \\
150 \text { hours for Tests } 1 \text { to } 3 \\
\text { and } \\
\text { until breakthrough for Test } 4\end{array}$} \\
\hline
\end{tabular}

\subsubsection{Physical Properties}

\section{Strength Characteristics}

The strength characteristics of the $30 \mathrm{~kg}$ batch of the preferred formulation will be checked for repeatability with previous data. In addition, the lift pipe attrition tests will be run. The green strength of the pellets will be determined as part of the pellet production process to insure quality control. The crush strength of cured, calcined, and reacted pellets will be determined. Two samples of reacted pellets from the integral tests will have their crush strength measured. One sample will be from the top of the bed which will have the most reacted pellets and the other sample will be from the bottom of the bed, with the least reacted pellets. The crush strength of the cured and calcined pellets will be determined before the chemical activity tests are run to insure pellet quality matches previous results. The attrition resistance of the calcined pellets will be measured using ASTM D4058-92 as well as with a special test. 
A special mechanical strength test will be performed in a pneumatic lift pipe/moving bed attrition apparatus described in Section 6.5. Lift pipe attrition tests will be run on a $14 \mathrm{~kg}$ calcined sample of the preferred formulation and on reacted pellets which will be retained from the fixed bed reactivity experiments. A test will also be run on inert GBF filter medium to provide a basis of comparison. The apparatus will operate 40 hours for each test for a total of three tests.

\section{Physical Morphology}

The bulk density, surface area, pore volume, median pore size and porosity will be determined for four samples of the preferred formulation. The four samples are: an air-cured sample, a sample calcined at $870^{\circ} \mathrm{C}$, a reacted sample from the top of the fixed bed of the integral test \#2 and a sample from the bottom of the bed from test \#2 as shown in Table 6 . Test \#2 is expected to be more representative of field conditions than the other test conditions.

\subsection{Engineering Reactor Model for Alkali Sorption}

The kinetic data from the integral reactor tests will be used to develop a kinetic expression for the reaction of alkali vapors with the clay sorbent. The kinetics will take into account the effect of alkali vapor concentration and the effect of $\mathrm{HCl}$ on reaction rates. The kinetic expression will be incorporated in an engineering model of the GBF. The GBF will be modelled as a countercurrent plug flow reactor such that sorbent removed from the bottom of the filter is re-introduced at the top of the filter. The model will predict the alkali concentration at the filter outlet and the sorbent life as a function of bed depth, sorbent velocity, alkali inlet concentration, gas composition, temperature and pressure.

\subsection{Evaluation of Clay Sorbent for Sorption of Trace Metals}

The objective of these tests is to evaluate the sorption of trace metals using the clay sorbent already developed for the control of alkali vapors. The initial screening tests of the clays showed the potential of each of the evaluated clays for reacting with lead, cadmium, barium, beryllium and chrome. The clay chosen for further evaluation was selected on the basis of its sodium sorption ability, its structural properties and its potential to react with these trace metals.

\subsubsection{Pellet Production}

For the evaluation of the sodium sorbent as a trace metals sorbent, an additional $14 \mathrm{~kg}$ of pellets will be fabricated for these tests and can be part of the fabrication done in Task 3.3.1. 


\subsubsection{Sorbent Saturation Capacity}

The objective of these tests is to determine the maximum sorption capacity of the clay sorbent for lead, cadmium, barium, beryllium and chrome without sodium present. A TGA will be used to determine the saturation capacity of the clay pellets for each of these trace metals. The tests will be run with artificially high concentrations of each trace metal in order to reduce run time. Table 7 gives the test conditions. The test duration will be such that the rate of adsorption at the end of the test is no more than $5 \%$ of the initial rate.

\subsubsection{Chemical Reactivity and Kinetics of Sorption of Trace Metals}

An integral reactor will be used to determine the reactivity of the clay sorbent with each of the above trace metals in the presence of sodium vapors. For each metal, there will be two integral tests. Test conditions are show in Table 8. There will be a total of 10 integral tests. Test duration will be 150 hours. After each test, the bed will be sectioned into 10 layers and each layer analyzed for sodium and the trace metal under evaluation.

\subsubsection{Strength Characteristics of Reacted Pellets}

Pellets from the top and bottom layers of the fixed beds used in the integral tests will be evaluated for crush strength. The crush strengths will be compared to those of pellets which have absorbed sodium. A total of 20 crush strength tests will be performed.

Table 7

Test Conditions for Sorbent Saturation With Trace Metal

Test Parameter

Gas Composition

Gas Temperature

Metal Chloride Concentration

Pressure

Space Velocity

$\mathrm{HCl}$ Concentration

Number of Tests

Minimum No. of Pellets Per Test 3
Value

$90 \% \mathrm{CO}_{2}, 10 \% \mathrm{H}_{2}$

$870^{\circ} \mathrm{C}$

$100 \mathrm{ppmv}$

$1 \mathrm{~atm}$.

$100,000 / \mathrm{hr}$

none and $100 \mathrm{ppm}$

10 
Table 8

Integral Reactor Tests for Trace Metal Sorption

\begin{tabular}{|c|c|c|c|}
\hline Gas type & $\begin{array}{c}\text { Temperature } \\
\left({ }^{\circ} \mathrm{C}\right)\end{array}$ & $0 \underset{\mathrm{HCl}}{\mathrm{ppmv}}$ & $\begin{array}{c}100 \mathrm{ppmv} \\
\mathrm{HCl}\end{array}$ \\
\hline Reducing & 870 & Test \#1 & Test \#2 \\
\hline \multicolumn{2}{|c|}{$\begin{array}{l}\text { Reducing gas composition: } \\
\text { Space velocity: } \\
\text { Reactor diameter: } \\
\text { Reactor length: } \\
\text { Pellet diameter: } \\
\text { Trace metal concentration: } \\
\text { Sodium concentration: } \\
\text { Test duration: }\end{array}$} & \multicolumn{2}{|l|}{$\begin{array}{l}90 \% \mathrm{CO}, 10 \% \mathrm{H}_{2} \\
1,000 / \mathrm{hr} \\
8 \mathrm{~cm} \\
30 \mathrm{~cm} \\
7 \mathrm{~mm} \\
40 \mathrm{ppmv} \\
400 \mathrm{ppmv} \\
150 \text { hours }\end{array}$} \\
\hline
\end{tabular}

\subsubsection{Engineering Reactor Model for Metal Sorption}

The kinetic data from the integral reactor tests will be used to develop a kinetic expression for the reaction of metal vapors with the clay sorbent. The kinetics will take into effect the concentration of metal vapor and the effect of $\mathrm{HCl}$ on reaction rates. The model will not take into account the possible interference of the sorption of one metal in the presence of metals other than sodium, since no data will be collected in which multiple trace metals are present in the gas stream. The effects of possible interference or competition between trace metals for reaction with the clay will be determined in field trials using real coal gas streams. The kinetic expressions will be incorporated in an engineering model of the GBF. The GBF will be modeled as a countercurrent plug flow reactor such that sorbent removed from the bottom of the filter is re-introduced at the top of the filter. The model will predict the metal vapor concentration at the filter outlet and the sorbent life as a function of bed depth, sorbent velocity, alkali inlet concentration, gas composition, temperature and pressure.

\subsection{Cost of Clay Sorbents}

Plant-scale processes will be developed to estimate the capital and operating cost to produce a GBF clay medium. The process will be based on bench scale process developed in Section 3.2. The production rates will be 500 ton/yr, 5,000 ton/yr and 50,000 ton/yr. 


\section{Table 9}

Summary of Tests and Analysis for Clay Sorbent

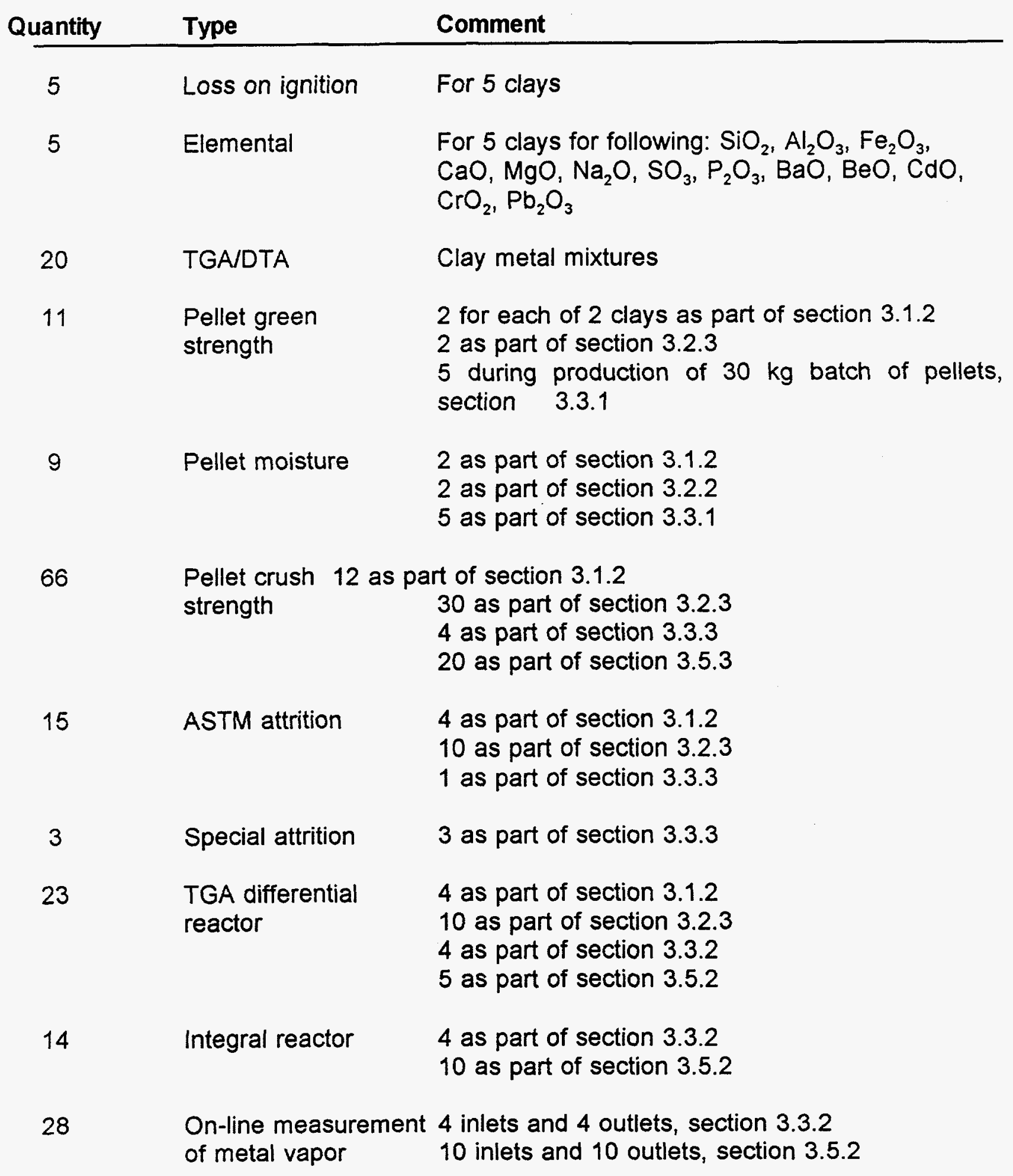


Table 9

Summary of Tests and Analysis (continued)

\begin{tabular}{|c|c|c|}
\hline Quantity & Type & Comment \\
\hline 4 & Bulk density & As part of Section 3.3.3 \\
\hline 4 & Pore volume & As part of Section 3.3.3 \\
\hline 4 & Median pore dia. & As part of Section 3.3.3 \\
\hline 4 & Surface area & As part of Section 3.3.3 \\
\hline 4 & Porosity & As part of Section 3.3.3 \\
\hline 148 & Total sodium & $\begin{array}{l}4 \text { as part of Section } 3.1 .2 \\
4 \text { as part of Section } 3.3 .2 \\
40 \text { as part of Section } 3.3 .2 \\
100 \text { as part of Section } 3.3 .5\end{array}$ \\
\hline 16 & $\begin{array}{l}\text { Water soluble } \\
\text { sodium }\end{array}$ & $\begin{array}{l}4 \text { as part of Section } 3.1 .2 \\
4 \text { as part of Section } 3.3 .2 \\
8 \text { as part of Section } 3.3 .2\end{array}$ \\
\hline 20 & Barium & 20 as part of Section 3.5 .4 \\
\hline 20 & Beryllium & 20 as part of Section 3.5 .4 \\
\hline 20 & Cadmium & 20 as part of Section 3.5 .4 \\
\hline 20 & Chromium & 20 as part of Section 3.5 .4 \\
\hline 20 & Lead & 20 as part of Section 3.5.4 \\
\hline
\end{tabular}




\subsection{TEST PLAN FOR DEVELOPMENT OF SODIUM-BASED SORBENTS FOR THE CONTROL OF HALOGENS AND METALLOIDS USING A GBF}

\subsection{Review Results from Current DOE Program}

The test plan for a halogen sorbent will build on the work being done by SRI International and RTI under a current DOE contract, DE-AC21-93MC30005, entitled "Development of Disposable Sorbents for Chloride Removal from High-Temperature Coal-Derived Gases" (Krishnan, 1994). The primary emphasis of this program is the investigation of different processes for the fabrication of sorbents suitable for $\mathrm{HCl}$ vapor removal in hot, coalderived gases at temperatures between $480^{\circ} \mathrm{C}$ and $650^{\circ} \mathrm{C}$. The results of this program will be reviewed to determine the most likely process and material to produce a GBF filter medium that can control halogens and particulates.

\subsection{Preparation of Sorbent}

A 35 pound batch of $6-8 \mathrm{~mm}$ spherical pellets will be produced using the most promising formulation determined in DOE Contract DE-AC21-93MC30005. Previous tests used smaller-sized pellets. All of the prepared pellets will be calcined at $550^{\circ} \mathrm{C}$ for 4 hours prior to chemical and physical evaluation.

\subsection{Chemical Reactivity of Sorbent}

The objective of these tests is to measure the chemical reactivity of the 6-8 $\mathrm{mm}$ spherical pellets and to compare their reactivity to previous results to insure consistency and to determine effects of increased particle size. The reactivity will be evaluated in a fixed bed, $8 \mathrm{~cm}$ diameter by $30 \mathrm{~cm}$ long contained in a quartz reactor, operated in an integral mode. The test conditions will be: $1000 / \mathrm{hr}$ space velocity, $550^{\circ} \mathrm{C}, 1 \mathrm{~atm}$. and $1750 \mathrm{ppmv}$ $\mathrm{HCl}$ inlet concentration. Gas composition will simulate an air-blown gasifier. The integral test will be run until the outlet chloride concentration exceeds $50 \mathrm{ppmv}$. After the test, the bed will be sectioned into 10 parts and each section analyzed for chlorine. In addition to the integral test, differential reactor tests will be run to determine the saturation capacity, maximum chloride content, of the larger sorbent spheres. Three differential tests will be run varying the exposure time such that one of the test durations is sufficient to saturate the sorbent. The differential tests will be at a space velocity of $100,000 / \mathrm{hr}$, gas temperature of $550^{\circ} \mathrm{C}$ and an inlet concentration of $2000 \mathrm{ppmv}$ of $\mathrm{HCl}$. The carrier gas will simulate that of an air-blown gasification process. Only a limited number of reactivity tests will be performed since these tests are meant to verify previous results.

\subsection{Physical Properties of Sorbent}

Crush strength of air-dried, calcined and reacted sorbent will be determined. ASTM attrition tests will be run on both calcined and reacted sorbent. Surface area, bulk density, pore volume, average pore diameter and porosity measurements will be made using the calcined and saturated sorbents. A thirty-pound sample of the calcined sorbent will be run in the special lift pipe moving bed attrition tester. The strength properties will be compared to those of the clay sorbents and to those of the inert GBF filter material. 


\subsection{Engineering Reactor Model for Halogen Sorbent}

The reactivity data from the integral test and data from the earlier DOE study will be used in an engineering model of the GBF as a reactor for halogen sorption. The model will be used to predict sorbent life and chloride outlet concentration as a function of bed depth, sorbent velocity, chloride inlet concentration, gas composition, temperature and pressure. The model will evaluate the merits of continuous replacement of spent sorbent versus periodic replacement of the entire filter material with fresh sorbent.

\subsection{Fabrication Cost Evaluation}

The cost data from the previous study will be updated to reflect any additional cost associated with the production of $7 \mathrm{~mm}$ spherical pellets. Previous work was with rounded cylindrical pellets. Also, cost estimates will be obtained for pilot-scale production of 150 to $300 \mathrm{ft}^{3}$ of sorbent for testing at DOE's Power Systems Development Facility.

\subsection{Trace Metalloid Sorption}

The objective of these tests is to determine the trace metalloid removal capability of the sorbent developed for the control of chlorides with a GBF. SRI's initial tests with the sodium-based sorbents indicated that they may also control the metalloids arsenic, selenium and antimony (Krishnan, 1986). Nahcolite removed antimony and selenium. Shortite and Dawsonite removed arsenic.

The maximum sorption capacity of the sodium-based clay sorbent selected for halogen removal will be determined using the double TGA system. In the first TGA, controlled vaporization of metal salts will be carried out to generate target quantities of metalloid vapors. In the second TGA, the weight gain by the sorbent pellet will be determined as a function of time to estimate the rate of absorption of metalloid. At the end of the tests, the reacted pellets removed from the TGA tests will be analyzed for the metal contents.

Two integral tests will evaluate the sorption of the two metalloids which show the most promise of capture in the TGA tests. For the integral test, the metalloid concentration will be $10 \mathrm{ppmv}$, chloride concentration will be $300 \mathrm{ppmv}$, gas composition will simulate an air-blown gasifier and gas temperature will be $550^{\circ} \mathrm{C}$. The test will end when the chloride outlet concentration reaches $50 \mathrm{ppmv}$. The bed will be sectioned into 10 layers and each layer will be analyzed for chlorine and the trace metalloid under investigation. 
Table 10

Summary of Tests for Evaluation of Sodium-Based Sorbents

\begin{tabular}{|c|c|c|}
\hline Quantity & Type of Test & Comment \\
\hline 3 & Crush strength & Air-dried, calcined and reacted pellets \\
\hline 2 & ASTM attrition & Calcined and reacted pellets \\
\hline 1 & Special attrition & 30-lb calcined pellets \\
\hline 2 & Surface area & Calcined and reacted pellets \\
\hline 2 & Bulk density & Calcined and reacted pellets \\
\hline 2 & Pore volume & Calcined and reacted pellets \\
\hline 2 & $\begin{array}{l}\text { Average pore } \\
\text { diameter }\end{array}$ & Calcined and reacted pellets \\
\hline 2 & Porosity & Calcined and reacted pellets \\
\hline 12 & TGA reactor & $\begin{array}{l}3 \text { for determination of } \mathrm{Cl} \text { saturation levels } \\
3 \text { for determination of } \mathrm{Se} \text { saturation levels } \\
3 \text { for determination of } \mathrm{Sb} \text { saturation levels } \\
3 \text { for determination of As saturation levels }\end{array}$ \\
\hline 3 & Integral reactor & $\begin{array}{l}1 \text { for chloride reactivity } \\
2 \text { for trace metalloids sorption }\end{array}$ \\
\hline 33 & Chlorine analysis & $\begin{array}{l}3 \text { for } \mathrm{Cl} \text { saturation tests } \\
10 \text { for } \mathrm{Cl} \text { integral test } \\
20 \text { for two trace metalloids integral tests }\end{array}$ \\
\hline 13 & Selenium analysis & $\begin{array}{l}3 \text { for determination of Se saturation levels } \\
10 \text { for integral test }\end{array}$ \\
\hline 13 & Antimony analysis & $\begin{array}{l}3 \text { for determination of } \mathrm{Sb} \text { saturation levels } \\
10 \text { for integral test }\end{array}$ \\
\hline 3 & Arsenic analysis & 3 for As saturation tests \\
\hline
\end{tabular}




\subsection{TEST PLAN FOR EVALUATION OF AMMONIA DECOMPOSITION CATALYST}

\subsection{Acquisition of Catalyst}

RTI has a DOE contract for the evaluation and development of ammonia decomposition catalyst for use in coal gasification processes, DEAC21-92MC29011. The most promising ammonia decomposition catalyst is Haldor-Topsoe's HTSR-1 (Gupta 1994). Twenty kilograms of $7 \mathrm{~mm} \pm 1 \mathrm{~mm}$ diameter spherical pellets will be obtained from HaldorTopsoe for evaluation as a GBF bed material. Should the RTI program determine a more suitable catalyst in its ongoing investigation, then that catalyst would be used instead of the HTSR-1.

\subsection{Confirmation of Catalyst Reactivity}

RTI will have completed an extensive evaluation of the reactivity of the chosen catalyst so that only a limited amount of additional testing will be required. The fixed bed reactor used for the integral tests in the development of clay sorbents will also be used as the reactor in the evaluation of the ammonia catalyst for use in a GBF. Table 11 shows the test conditions to be used for screening tests. The objective of the first screening test is to demonstrate that the $7 \mathrm{~mm}$ spherical catalyst has the same reactivity as smaller shapes previously evaluated in the RTI program.

The GBF operates at a space velocity of about $1,000 \mathrm{hr}^{-1}$ and a fixed bed for the catalytic decomposition of ammonia would operate at a space velocity of $10,000 \mathrm{hr}^{-1}$. In order to make the space velocity between the two types of reactors compatible, the GBF bed could be composed of a mixture of catalyst and other filter material. At a space velocity of $10,000 \mathrm{hr}^{-1}$ and a bed of $100 \%$ catalyst, the ammonia residence time with respect to the catalyst would be the same as a bed containing $10 \%$ catalyst operating at a space velocity of $1,000 \mathrm{hr}^{-1}$. The objective of screening tests 2,3 and 4 is to determine the ratio of catalyst to clay sorbent which needs to be present in a GBF to be able to control ammonia. Test 5 will determine if similar results are obtained with an inert medium rather than with the clay medium. The gas composition used for these tests corresponds to the predicted gas composition for the Kellogg entrained flow gasifier which will be tested with a GBF at the Power Systems Development Facility. The outlet concentration of ammonia from the screening tests will be monitored with on-line equipment in order to evaluate the effectiveness of the catalyst.

Based on the results of the screening tests, a determination will be made as to the ratio of catalyst to clay sorbent or inert GBF media for use at space velocity of $1,000 \mathrm{hr}^{-1}$. A longer term, 100-hour test will evaluate the performance of this ratio of catalyst to clay sorbent at a space velocity of $1,000 \mathrm{hr}^{-1}$. Other test conditions for the 100-hour test will remain the same as for the screening tests except that $40 \mathrm{ppm}$ of $\mathrm{NaCl}$ will be introduced into the gas stream after the first 25 hours of the test. The introduction of $\mathrm{NaCl}$ should demonstrate that sodium and the clay sorbent have no deleterious effect on the catalytic 
decomposition of ammonia.

\subsection{Mechanical Integrity of Ammonia Decomposition Catalyst}

The purpose of these tests is to demonstrate that the ammonia decomposition catalyst has the structural properties required of a GBF filter material. The following tests will be performed.

\subsubsection{Crush Strength}

The crush strength of fresh catalyst and catalyst from the 100-hour test will be measured.

\subsubsection{ASTM Attrition Test}

ASTM attrition test will be performed on the fresh catalyst and on catalyst used in the 5-hour screening test.

\subsubsection{Special Attrition Test}

Three kilograms of fresh catalyst which have been held at $850^{\circ} \mathrm{C}$ for 4 hours will be supplied to Combustion Power by its subcontractor. Combustion Power will test a mixture of the catalyst and inert GBF filter material in the lift pipe attrition tester used for evaluation of attrition in a GBF environment.

\subsection{Engineering Model}

The kinetic data from the previous RTI program and that collected in the current program will be used to predict catalyst life and clay sorbent life for a mixture of clay sorbent and catalyst used in a GBF for ammonia and alkali control. 


\section{Table 11}

\section{Screening Test For Ammonia Decomposition}

\begin{tabular}{|c|c|c|c|c|}
\hline Test No. & $\begin{array}{c}\text { Space } \\
\mathrm{hr}^{-1}\end{array}$ & Velocity & Admixture & $\begin{array}{l}\text { Percent Admixture by Vol. } \\
(\%)\end{array}$ \\
\hline 1 & 10,000 & & None & None \\
\hline 2 & 1,000 & & Clay pellets & 95 \\
\hline 3 & 1,000 & & Clay pellets & 90 \\
\hline 4 & 1,000 & & Clay pellets & 80 \\
\hline 5 & 1,000 & & nert GBF media & To be determined \\
\hline \multicolumn{2}{|c|}{$\begin{array}{l}\text { Gas Composition } \\
\text { Temperature: } \\
\text { Pressure: } \\
\text { Test Duration: }\end{array}$} & \multicolumn{3}{|c|}{$\begin{array}{l}\mathrm{CO}-17 \\
\mathrm{H}_{2} \mathrm{~S}-0.0 \\
850^{\circ} \mathrm{C} \\
1 \text { atm } \\
5 \text { hours }\end{array}$} \\
\hline
\end{tabular}

\subsection{DESCRIPTION OF TEST APPARATUS}

\subsection{Themal Analysis}

A DuPont 1090 thermal analysis system consisting of a TGA and a DTA and interfaced with an IBM PC and a Hewlett Packard plotter will be used for the screening tests. The system is controlled by a state-of-art Thermal Analysts System (TA 2000) via a computer module which allows extensive thermal programming capabilities, versatile and accurate analysis modules, and a wide range of analysis software. This system provides a series of thermal programming features including:

- 18 available functions for construction of thermal programs and methods;

- Memory storage for up to 15 methods containing up to 60 program segments;

- Heating and cooling rates in operator selected increments of $0.1^{\circ} \mathrm{C} / \mathrm{min}$;

- Isothermal and Isotrac programming; and

- Automatic control of purge gas and event accessories. 
A battery of rotameters connected to various gas cylinders provides a wide range of gas compositions. A Harvard Apparatus syringe pump, capable of operating in the 0.005 to $5 \mathrm{~mL} / \mathrm{min}$ range, is used to generate steam at any desired flow rate. In these proposed programs, simultaneous use of a TGA/DTA system will allow the measurement of both the change in the sample weight (TGA) as well as energy or phase changes occurring in the sample (DTA) as a function of temperature. Any phase transformation occurring in the sample can be rapidly distinguished using this technique.

\subsection{Pellet Preparation Equipment}

Two laboratories will be used for the preparation of extruded and disk pelletized sorbents. RTI proposes to use LCl Corporation's Test Center in Charlotte to do extrusion/spheronization trial runs. The $\mathrm{LCl}$ Test Center houses complete particle forming and characterization facilities. $\mathrm{RTI}$ has an agreement with $\mathrm{LCl}$ to prepare sorbent materials for a daily rental rate of the Test Center for $\$ 1,500$ which includes service of one $\mathrm{LCl}$ engineer, one trained technician and cleaning and necessary supplies along with use of all the test equipment. Using a combination of an extruder and a spheronizer (also called marumerizer), $3 \mathrm{~mm}$ and $7 \mathrm{~mm}$ diameter round balls of the sorbent will be prepared. RTI has used a Fuji twin screw extruder and a spheronizer in the past to produce spherical pellets of iron oxide, zinc ferrite, zinc titanate, alumina and nahcolite.

For the preparation of disk pelletized sorbents, RTI plans to use Allis Mineral Systems (AMS). A continuous balling pan, available at AMS, is a $101.6 \mathrm{~cm}$ diameter disc having a sidewall adjustable in height from 2.54 to $22.9 \mathrm{~cm}$. It may be rotated at speeds varying from 12 to $24 \mathrm{rpm}$. As the pan rotates, its slope can be varied from $40^{\circ}$ to $56^{\circ}$ from the horizontal. AMS also has a laboratory $14^{\prime \prime}$ balling pan which can be used to effectively prepare small samples and the preparation recipe can then be scaled up.

The pans are equipped with a fixed sidewall scraper and a rotating bottom scraper which serves to maintain a controlled buildup of material being balled. This coating helps feed materials, seeds and under-sized balls to tumble actively in the pan. High pressure atomizer water sprays allow moisture addition during balling. Figure 1 shows a schematic diagram of balling pan load.

Ancillary equipment for the balling pan circuit includes the following:

- A Simpson mix muller to premix additives and water,

- A surge bin and weight-belt feeder for controlling material feed rate to the pan,

- A PreKay mixer to condition pan feed,

- A double-deck vibrating product screen, and

- Transfer conveyors to complete the circuit. 


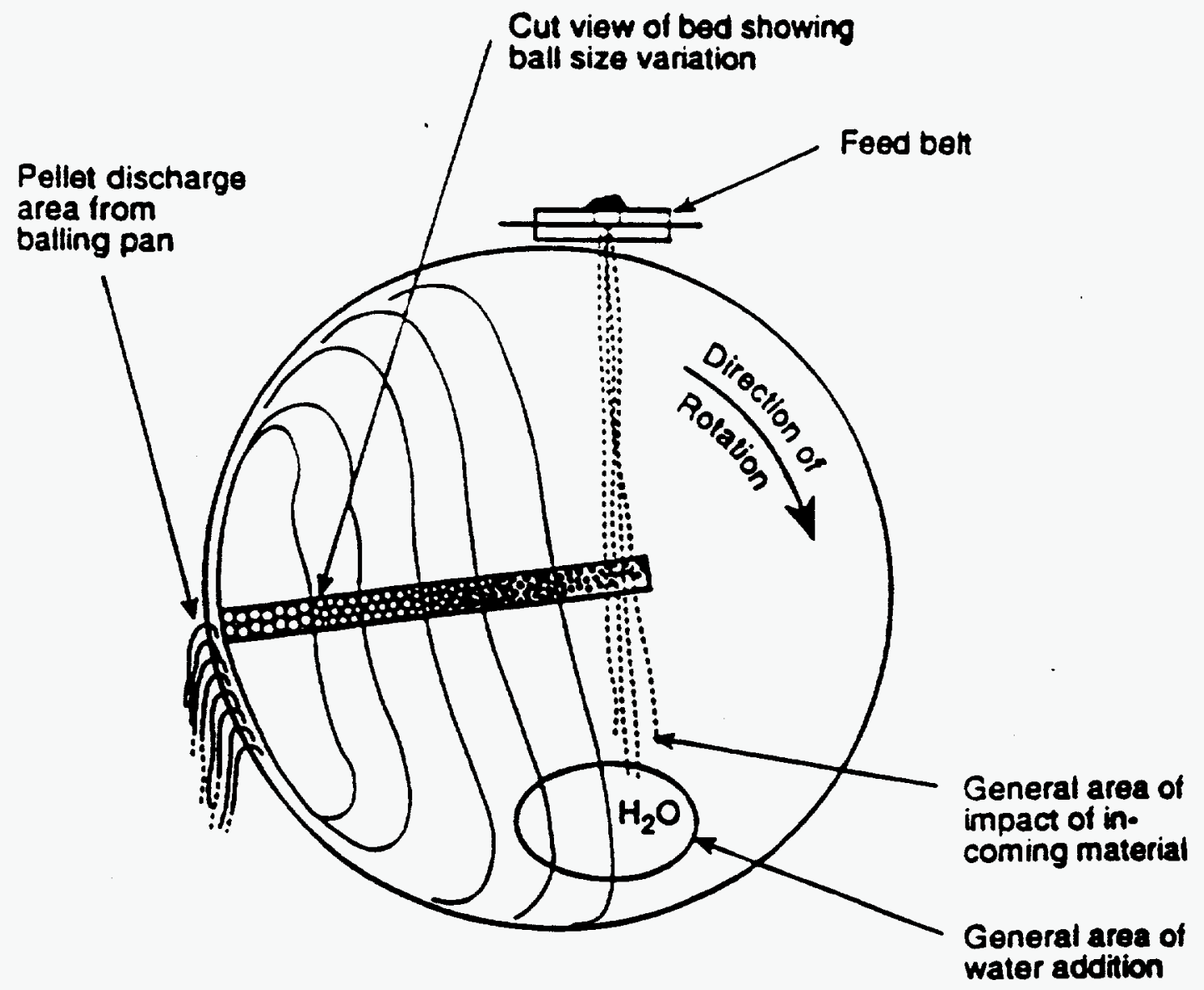

Figure 1 Schematic Diagram of Balling Pan Load 


\subsection{Double TGA Apparatus for Measurement of Clay Reactivity}

The chemical reactivity of each type and size of clay pellet will be determined from TGA tests by comparing the rate of adsorption of sodium and percent weight gain using a simulated fuel gas containing $90 \% \mathrm{CO}_{2}$ and $10 \% \mathrm{H}_{2}$ at $870{ }^{\circ} \mathrm{C}$. Forty ppm of sodium vapors will be introduced in the coal gas by controlled vaporization of $\mathrm{NaCl}$ crystal in a connected TGA.

Figure 2 shows a schematic of the proposed double TGA system. RTI currently has a CAHN 1000 Electrobalance Unit which will be used to monitor the weight changes in the sorbent pellet as a function of time and/or temperature. RTI proposes to buy a second microbalance unit to be employed for controlled generation of alkali vapors. This unit will essentially contain a microbalance with a data acquisition system.

The proposed system is similar to one used by Mulik et al (1983) at Westinghouse in which one balance supported a crucible full of alkali salt, while the other supported a pellet of candidate material. In the proposed system, a provision will be made to house up to 4 additional pellets onto a quartz screen to expose them to alkali vapors. These pellets can than be used for strength measurements and chemical analysis for $\mathrm{Na}$ and other metals.

We propose to use quartz tubes in this study as used by Mulik et al (1983), Haas et al (1981). Nychrome heaters will be used to heat the reactor to desired temperatures. Precise temperature control will be achieved using a series of PID temperature controllers. A total gas flow rate of about 1 SLPM will be used in these tests. Our estimates indicate that space velocity past the sorbent pellet in this double TGA system will be well above $100,000 / \mathrm{hr}$.

After the assembly of the reactor system, a shakedown test will be made to confirm the $\mathrm{Na}$ concentration in the gas phase. This will be done by hanging a $\mathrm{NaCl}$ crystal in the microbalance and heating to desired temperature so as to generate $40 \mathrm{ppm}$ of $\mathrm{Na}$ vapors. The second TGA will not have a sorbent pellet hanging, but it will be heated to $870^{\circ} \mathrm{C}$. The outlet gas will be cooled in a ceramic filter to condense and collect the alkali. The alkali deposits on the filter will be analyzed for their $\mathrm{Na}$ content to obtain a mass balance.

In the TGA runs, weight profiles of rate of sodium vaporization as well as rate of alkali pickup by sodium will be determined by continuous data acquisition.

\subsection{Fixed Bed Reactor for Integral Tests of Clay Reactivity}

The reactor system for these tests will be designed and constructed at RTI. Figure 2 shows a conceptual schematic diagram of the proposed system. The reactor will 
be constructed of either quartz or very high-purity alumina as both these materials have been used in the past in these tests. It will be preferable to use quartz

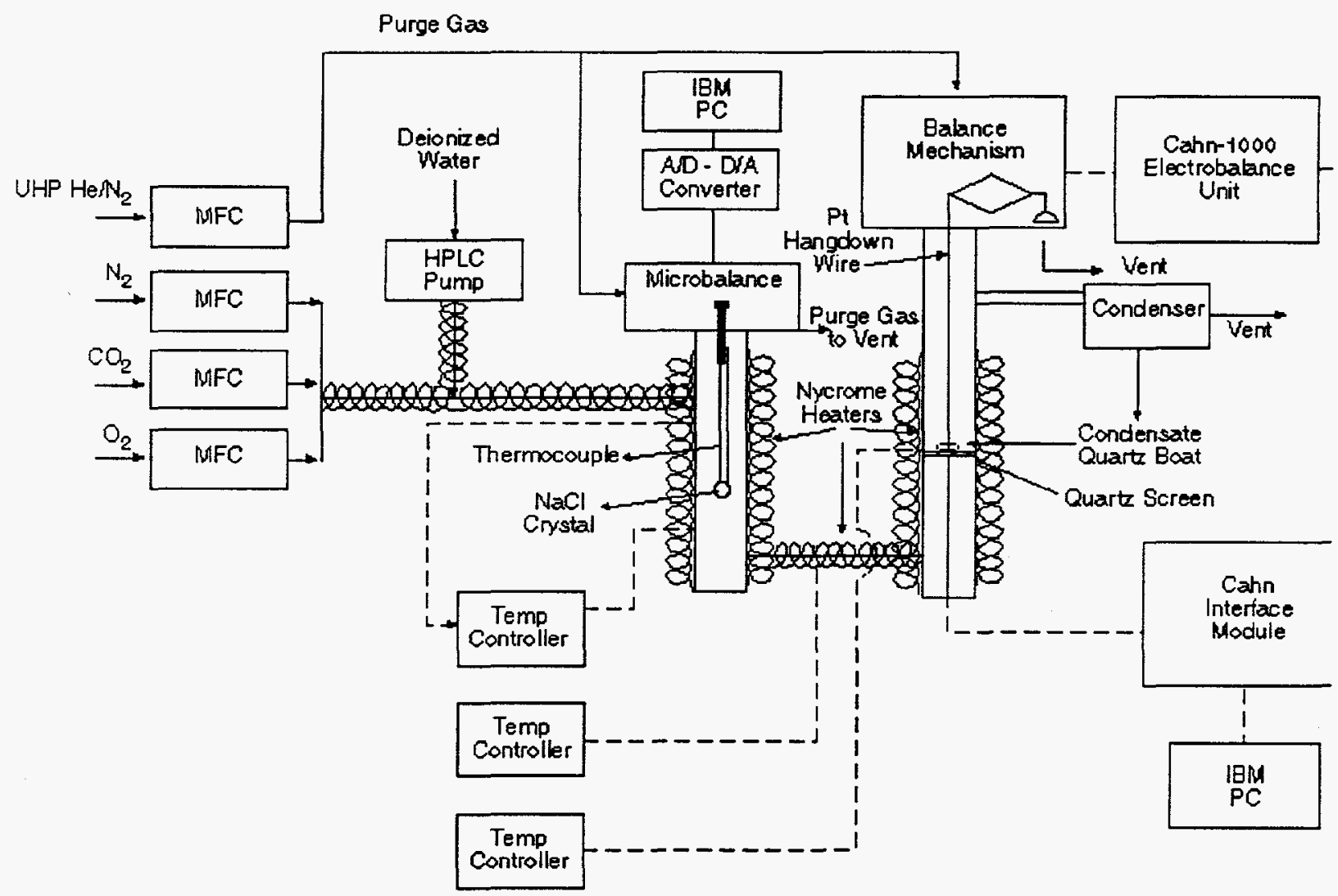

Figure 2 Double TGA Apparatus for Clay Sorbent Reactivity Studies

because of its easy availability and ease in the fabrication. But during our initial tests in the double TGA system, it is found that quartz acts as a sink for sodium vapors, it will be replaced by high purity alumina used in sodium vapor lamps as used by McLaughlin (1990).

Successful design and operation of the proposed bench system will be highly challenging in two aspects, one is the controlled generation of sodium vapors and secondly the on-line analysis of reactor exit gas for its $\mathrm{Na}$ vapor content. Based on our extensive literature review and extensive experience in handling trace quantities of heavy metals for EPA and other agencies, we propose two potential approaches for generation of $40 \mathrm{ppmv}$ (or $1000 \mathrm{ppmv}$ in Test 4) of the sodium vapors. The simplest approach will be to use a nebulizer in which a $\mathrm{NaCl}$ solution is atomized in a high temperature zone. Most commercial nebulizer systems are intended for room temperature and are therefore constructed of inert materials 


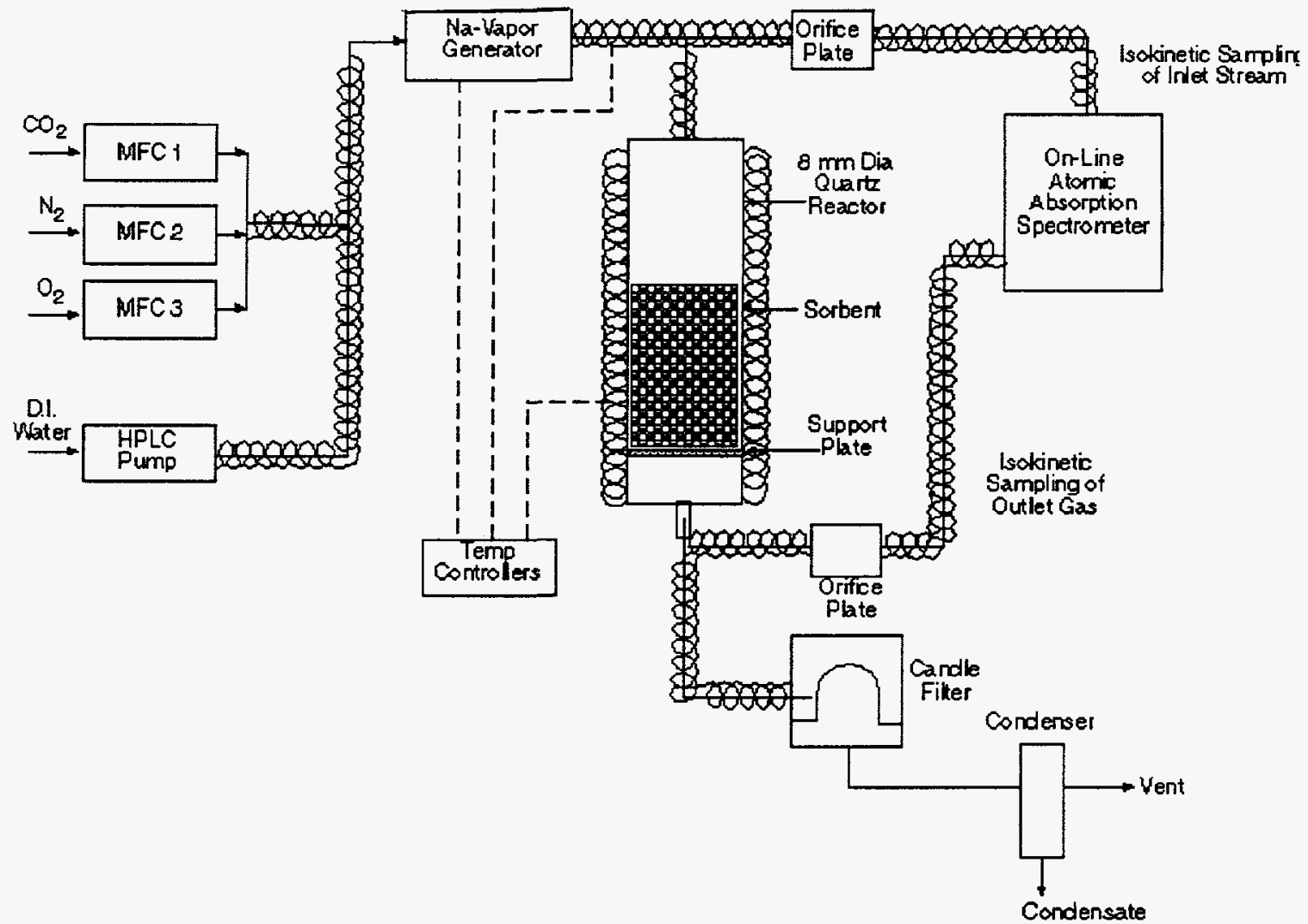

Figure 3 Integral Fixed Bed Test Apparatus for Measuring Clay Reactivity

such as teflon and polyethylene. Clearly these materials are unsuitable for this application and, as stated above, materials such as quartz or alumina must be used.

In this approach, metered quantities of $\mathrm{NaCl}$ solution will be passed through a $1 / 16$-in quartz capillary directly into the hot gas stream. Although some sputtering might occur as the liquid in the capillary will extend in both the directions at the very end of the capillary closest to the hot gas stream, it is expected that the aerosol generation should be fairly uniform.

The alternate approach is to disperse the $\mathrm{NaCl}$ onto a high surface area support and heat this material in a closely controlled temperature region so as to obtain equilibrium vapor generation by vaporizing $\mathrm{NaCl}$. This approach has been used by a number of investigators including SRI International (Krishnan et al, 1987) and Schulz (1994). Needless to say that any cold regions in the reactor system downstream of the $\mathrm{Na}$ vapor generator will promote $\mathrm{Na}$ condensation; therefore temperature of the transfer lines must be controlled in a very narrow window. As stated previously, this will not be a trivial task and few trial and error runs will be made to establish controlled generation of sodium. 
Generation of $90 \% \mathrm{CO}_{2}$ and $10 \% \mathrm{H}_{2}$ mixture will be fairly straight forward. Bottled gases containing pure $\mathrm{CO}_{2}$ and $\mathrm{H}_{2}$ will be used and blended by metering them by a series of electronic mass flow controllers. At a space velocity of 1000 per hour, the total gas flow rate will be about 100 SLPM. This gas will be preheated using a preheater and a superheater and sodium vapors will be blended in the hot gas to prevent condensation. The next challenge is to perform the on-line measurement of sodium vapors. We propose to use a fairly simple atomic absorption spectrometry system. With this system, an air/acetylene flame is normally used for excitation of a fine aerosol $(<10 \mu \mathrm{M})$ of standard aspirated solution containing the analyte metal. However, in order to prevent the condensation of $\mathrm{Na}$ vapors, this system will be modified to accomplish this on-line measurement. The nebulizer and the spray chamber assembly that normally crates aerosols would now be eliminated and would be replaced by a mixing chamber fabricated from alumina or quartz. The Al/quartz chamber would be directly interfaced with the titanium burner head. Before using this system on-line, a series of scoping tests will be performed to establish the accuracy and reproducibility of this technique for analysis of $\mathrm{Na}$ vapors in coal gas environments.

After each test, the bed will be sectioned into 10 intervals and the total sodium will be determined for each section of the bed. Water soluble sodium will also be determined for the top and bottom layers of the bed.

\subsection{Lift Pipe Attrition Apparatus}

The lift pipe moving bed attrition apparatus is shown in Figure 1. The apparatus simulates the pneumatic transport and recycle that pellets would endure in GBF operation. Approximately $14 \mathrm{~kg}$ of calcined pellets are used to fill the moving bed section of the apparatus. Ten psig air is supplied to the test apparatus. Air flow to the ell valve at the bottom seal leg controls the filter medium circulation rate. A second stream of air to the bottom of the lift pipe conveys the circulating medium to a disengagement vessel at the top of the lift pipe. The lift pipe air is discharged through a bag filter which catches any material attrited from the medium in the lift pipe. A third stream of air purges the moving bed test section of any fines generated in this region. The purge gas from the moving bed test section passes through a separate filter before being discharged. No solids should be picked up by the moving bed purge gas since this gas simulates the flow of coal gas through the filter. Any solids in this stream would be carried over into the turbine. Up to a $5 \%$ attrition rate in the lift pipe gas would be acceptable since this gas would also contain the particulate removed from the coal stream. The percent attrition loss is calculated in the same manner as ASTM procedure D 4058-92. 


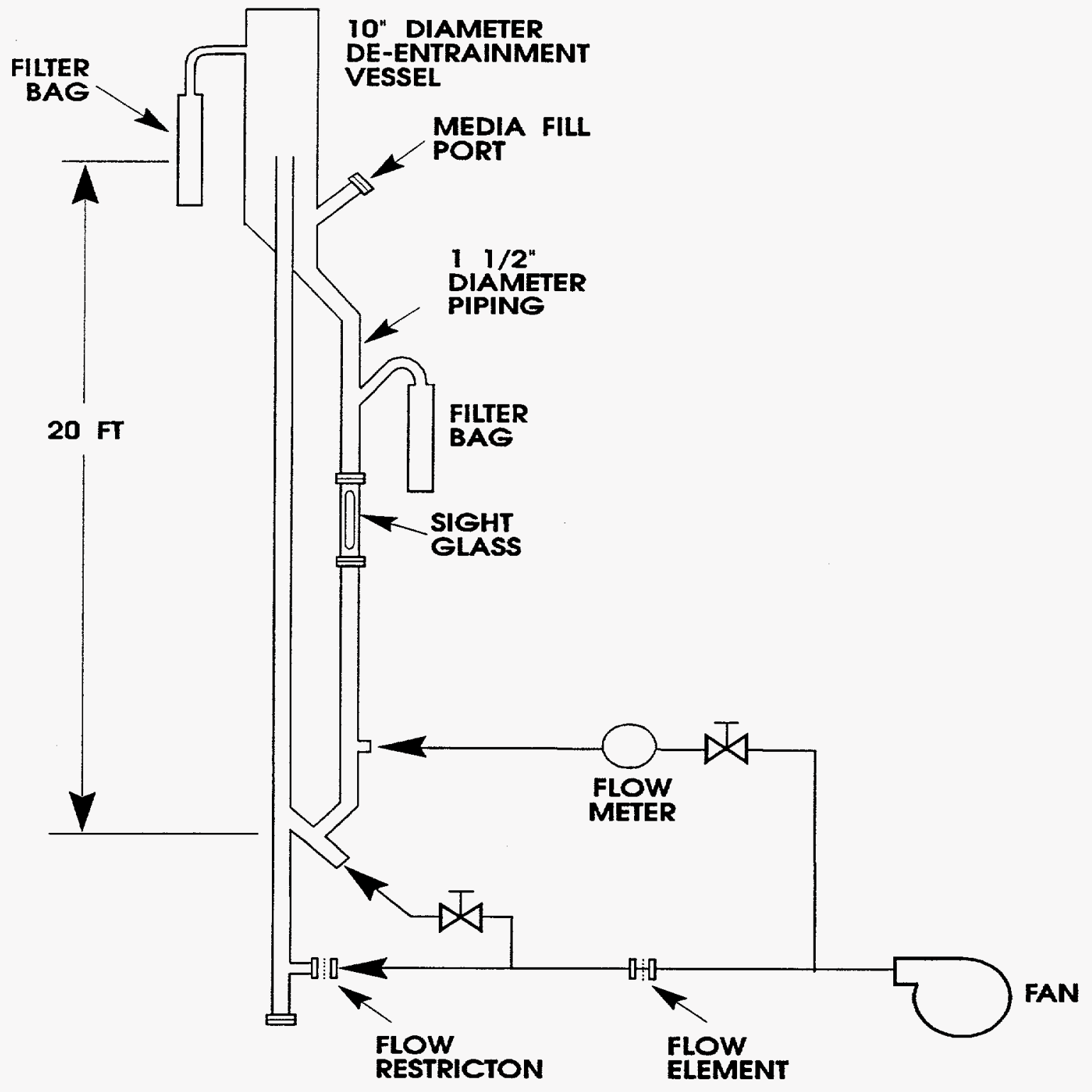

Figure 4 Pneumatic lift pipe/ moving bed attrition apparatus 


\subsection{Apparatus for Determining Reactivity of Sorbents for Halogens and Metalloids}

Figure 5 shows a schematic diagram of this test facility. Currently $R T I$ is using $2.6-\mathrm{cm}$ and $5.1-\mathrm{cm}$ quartz reactors; however, to provide sufficient $L / D$ ratio to prevent gas channelling, these reactors will be replaced by a $8-\mathrm{cm}$ dia quartz tube. This quartz reactor will be housed in a three zone furnace with a total of 36 -in long heated zone. The simulated coal gas will be generated using an existing gas delivery system. This gas delivery system consists of six electronic mass flow controllers and a HPLC pump. Pure bottled gases The coal gas will be preheated using a rod heater. The gas exiting the reactor will pass through a water jacketed condenser to condense out $\mathrm{HCl}$ vapors. The $\mathrm{HCl}$ content of the coal gas will be analyzed on-line using an existing ion chromatograph (IC) system (Model DX-100 from Dionex Corporation). A small flow of the condensate is continuously pumped into the IC using a peristaltic pump. This provides a cumulative concentration of $\mathrm{HCl}$ in the catch pot which is then differentiated to determine the instantaneous concentration at any point of time.

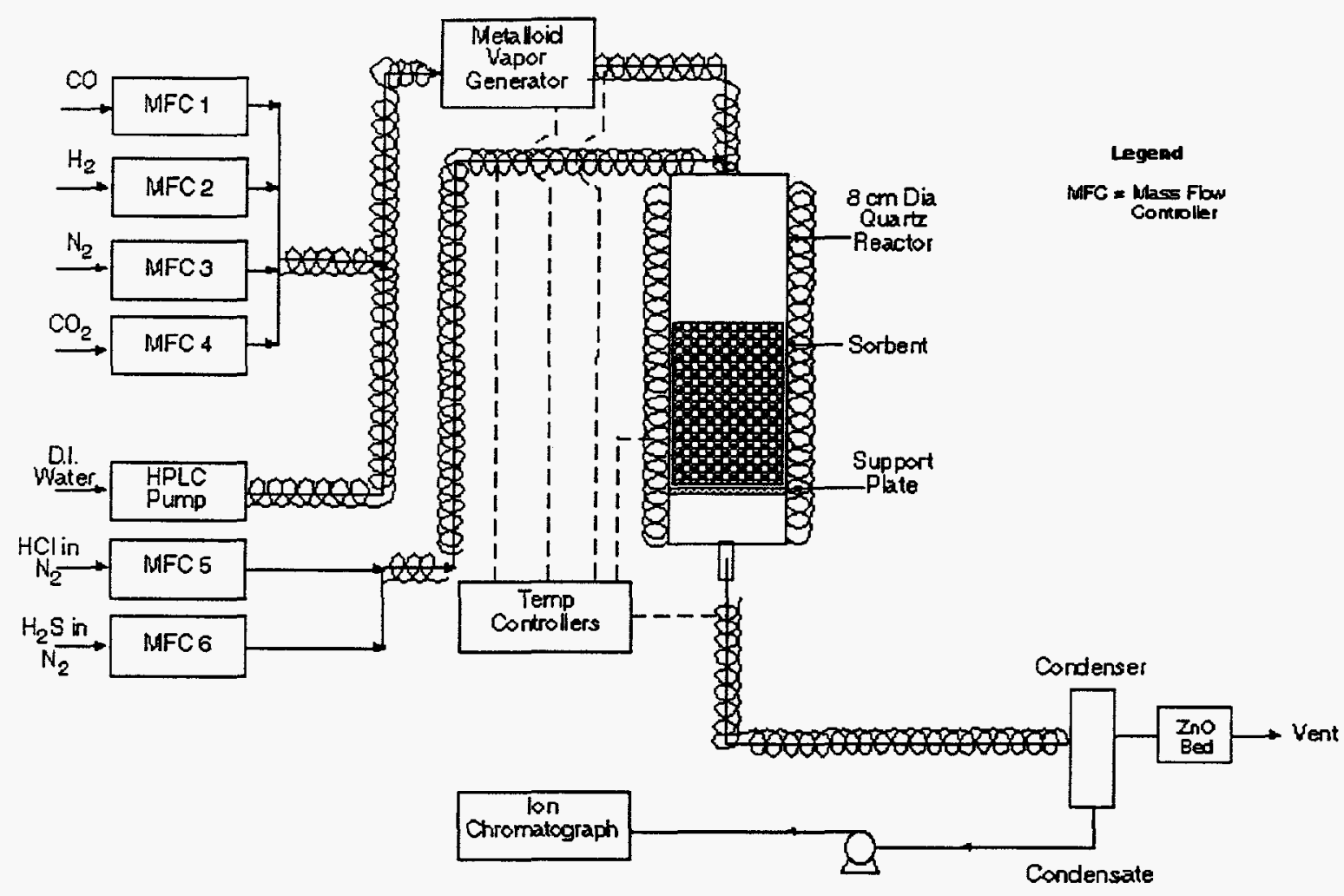

Figure 5 Apparatus for Measurement of Halogen and Metalloid Reactivity 


\subsection{Apparatus for Determining Ammonia Catalyst Reactivity}

In the test setup shown in Figure 6, a $8-\mathrm{cm}$ diameter quartz reactor will be used in a fixed-bed mode. This reactor will be housed in a 3-zone furnace capable of heating up to $1200^{\circ} \mathrm{C}$. A simulated coal gas mixture will be generated using a gas delivery system consisting of five electronic mass flow controllers and a HPLC pump. Bottled gases will be used for carbon monoxide, ammonia/hydrogen mixtures, nitrogen and carbon dioxide. Also, provision will be made to introduce $\mathrm{HCl}$, if necessary, using a nitrogen/ $/ \mathrm{HCl}$ mixture. After mixing and preheating, the simulated coal gas mixture will be passed through a 30 $\mathrm{cm}$ deep bed of catalyst at a desired space velocity. The gas leaving the reactor will be analyzed for its ammonia concentration using a Hewlett Packard 5890 gas chromatograph equipped with photo-ionization (PID) and thermal conductivity detectors (TCD). It is to be noted that the sample stream to be fed into the GC has to be hot to prevent condensation of steam as well as to minimize formation of ammonium carbonate and ammonium sulfide. This gas analysis system has been successfully tested and used in RTI's current project.

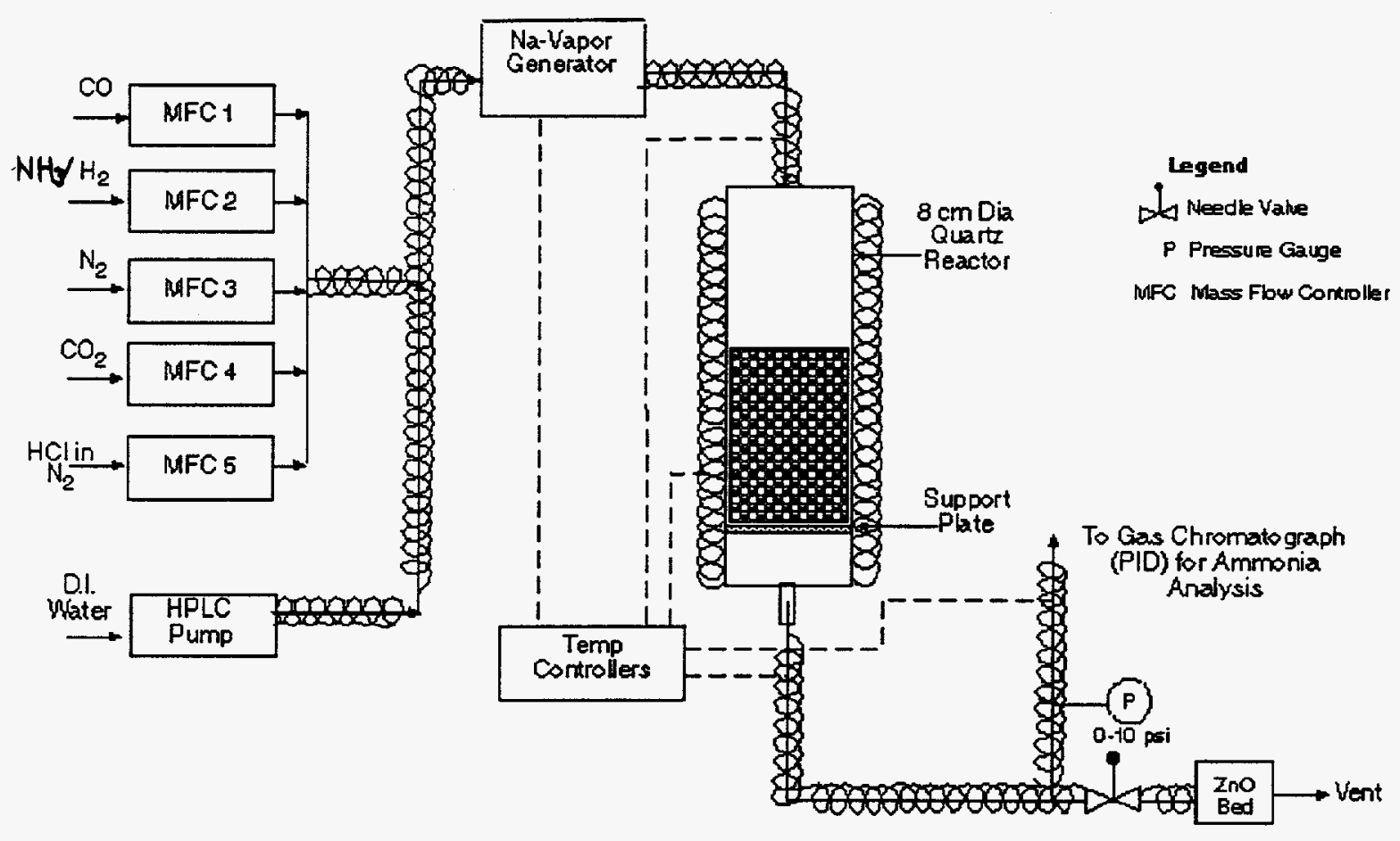

Figure 6 Apparatus for Determining Reactivity of Ammonia Catalyst 


\subsection{EVALUATION OF MULTI-CONTAMINANT CONTROL SORBENTS IN FIELD TRIALS}

Combustion Power Company is testing its moving granular bed filter at the Power Systems Development Facility (PSDF) at Southern Company Services under contract C93-00134. These tests will establish the suitability of the GBF for particulate removal in high-pressure, high-temperature coal gas streams. After completion of the particulate removal tests, there may be the opportunity to test the GBF for multi-contaminant control. Such testing would be performed under modification of our current contract with Southern Company Services.

It is assumed that some of the proposed GBF filter media will show sufficient promise to merit further evaluation in an operating GBF. Field tests will allow the evaluation of the sorption characteristics of the filter medium in the presence of coal gas rather than a simulated test mixture. It will also allow an evaluation of the strength and attrition resistance. These characteristic could effect the particulate capture efficiency of the GBF. Only through field trials will we be able to determine the suitability of the developed sorbent for the collection of particulate and the contaminant for which the sorbent is designed to collect.

It will be necessary to fabricate $150 \mathrm{ft}^{3}$ of each sorbent to be tested in the GBF at the PSDF. Little, if any, modification to the GBF will be necessary for the sorbent evaluation tests. It should take about a month to evaluate each sorbent. In the field test, the GBF would be operated in both gasification and combustion modes and at various operating temperatures. Particulate and contaminant concentrations will be measured in the gas stream before and after the filter. Periodically, samples of the filter material will be removed from the filter to measure the increase in contaminant concentration. Prior to the initiation of the field tests, a detailed test program would be prepared. After the formal evaluation period, the GBF could continue to operate with the sorbent filter material to get long-term performance data.

\subsection{Schedule}

The following Ghant charts shows the proposed schedule for the base program and the three options 
Project Schedule

Development of Moving-Bed Filter Technology for Multi-Contaminant Control

\begin{tabular}{|c|c|c|c|c|c|c|c|c|c|c|c|c|}
\hline \multirow[b]{2}{*}{ Task/Element } & \multicolumn{12}{|c|}{ Months after project initiation } \\
\hline & 2 & 4 & 6 & 8 & 10 & 12 & 14 & 16 & 18 & 20 & 22 & 24 \\
\hline \multicolumn{13}{|l|}{ Base Program-Develop Clay Sorbents } \\
\hline \multicolumn{13}{|c|}{$\begin{array}{l}\text { Option 1: Evaluation of Clay Sorbents for Sorption of } \\
\text { Trace Metals }\end{array}$} \\
\hline \multirow{2}{*}{\multicolumn{13}{|c|}{$\begin{array}{l}\text { Option 2: Development of Sodium-based Sorbents for } \\
\text { the Control of Halogens and Metaloids Using a GBF }\end{array}$}} \\
\hline & & & & & & & & & & & & \\
\hline & & & & & & & & & & & & \\
\hline
\end{tabular}


Project Schedule

Base Program-Development of Clay Sorbents

\begin{tabular}{|c|c|c|c|c|c|c|c|c|c|c|c|c|c|}
\hline & \multirow[b]{2}{*}{ Task/Element } & \multicolumn{12}{|c|}{ Months after project initiation } \\
\hline & & 1 & 2 & 3 & 4 & 5 & 6 & 7 & 8 & 9 & 10 & 11 & 12 \\
\hline \multirow[t]{3}{*}{3.1} & Screening of Sorbents & & & & & & & & & & & & \\
\hline & 3.1.1 Thermal Analysis & & & & & & & & & & & & \\
\hline & 3.1.2 Selection of Two Clays & & & & & & & & & & & & \\
\hline \multirow[t]{4}{*}{3.2} & Evaluations of Fabrication Methods & & & & & & & & & & & & \\
\hline & 3.2.1 Binders & & & & & & & & & & & & \\
\hline & 3.2.2 Pelletization Technique & & & & & & & & & & & & \\
\hline & 3.2.3 Evaluation/Selection of One & & & & & & & & & & & & \\
\hline \multirow[t]{4}{*}{3.3} & Evaluation of Preferred Formulation & & & & & & & & & & & & \\
\hline & 3.3.1 Pellet Production & & & & & & & & & & & & \\
\hline & 3.3.2 Physical Properties & & & & & & & & & & & & \\
\hline & 3.3.3 Chemical Reactivity and Kinetics & & & & & & & & & & & & \\
\hline 3.4 & Engineering Reactor Model & & & & & & & & & & & & \\
\hline
\end{tabular}

Deliverables

a: Contractors' Review Meeting Paper

b: $15 \mathrm{~kg}$ of Pellets for Attrition Tests

c: Project Briefing to CPC/METC

d: Draft Final Report to CPC

e: Revised Final Report to CPC 


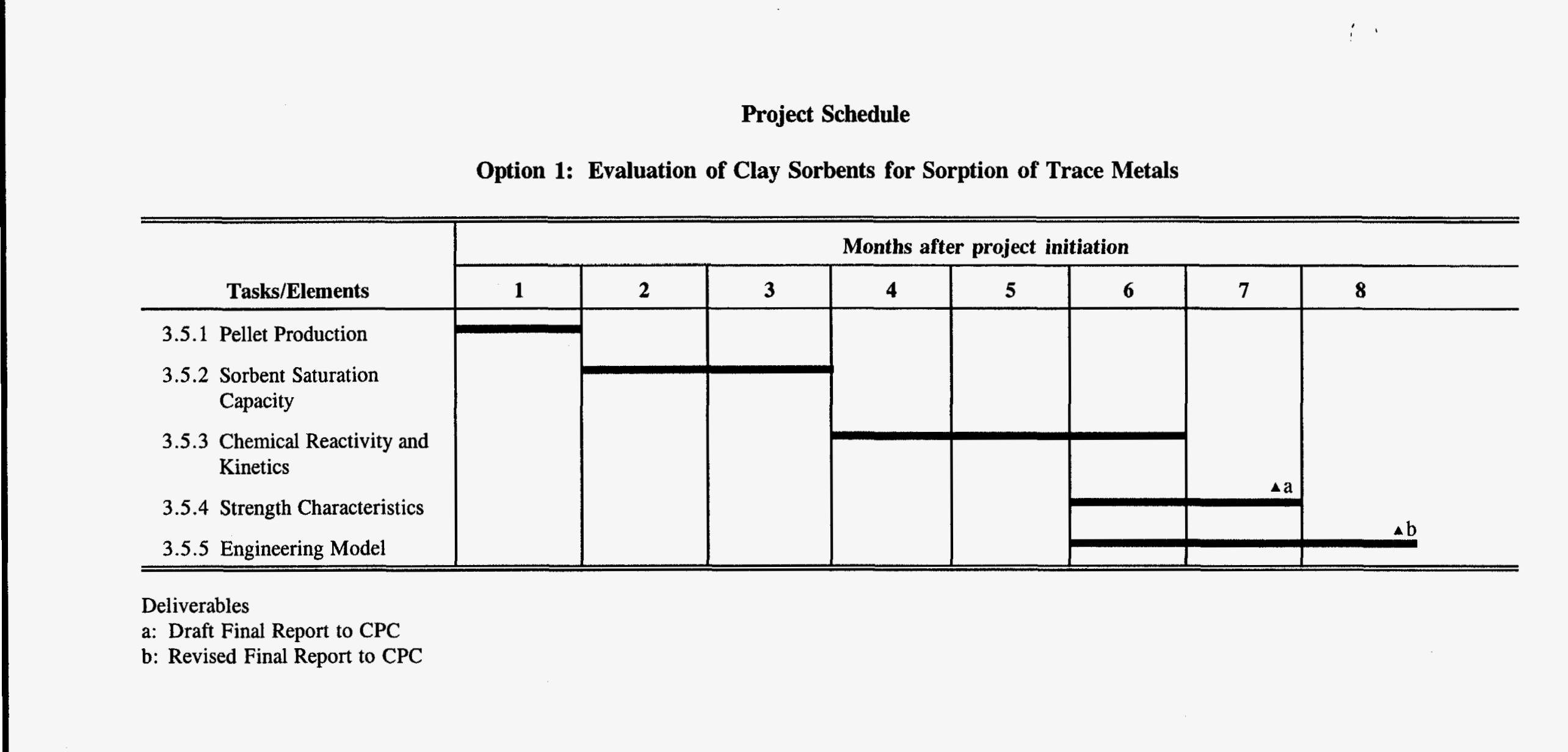




\section{Project Schedule}

Option 2: Development of Sodium-based Sorbents for the Control of Halogens and Metaloids Using a GBF

\begin{tabular}{|c|c|c|c|c|c|c|c|c|}
\hline & \multirow[b]{2}{*}{ Tasks/elements } & \multicolumn{7}{|c|}{ Months after project initiation } \\
\hline & & 1 & 2 & 3 & 4 & 5 & 6 & 7 \\
\hline 4.1 & Review Results from Current DOE Program & & & & & & & \\
\hline 4.2 & Preparation of Sorbent & & & & & & & \\
\hline 4.3 & Chemical Reactivity of Sorbent & & & & & & & \\
\hline 4.4 & Physical Properties of Sorbent & & & & & & & \\
\hline 4.5 & Engineering Reactor Model for Halogen Sorbent & & & & & & & \\
\hline 4.6 & Fabrication Cost Evaluation & & & & & & & \\
\hline 4.7 & Trace Metaloid Sorption & & & & & & & \\
\hline
\end{tabular}

Deliverables

a: Sorbent for attrition tests to CPC

b: Draft Final Report

c: Revised Final Report 


\section{Project Schedule}

Option 3: Evaluation of Ammonia Decomposition Catalyst

\begin{tabular}{|c|c|c|c|c|c|c|}
\hline \multirow{2}{*}{\multicolumn{2}{|c|}{ Task/Element }} & \multicolumn{5}{|c|}{ Months after project initiation } \\
\hline & & 1 & 2 & 3 & 4 & 5 \\
\hline 5.1 & Acquisition of Catalyst & & & & & \\
\hline 5.2 & Confirmation of Catalyst Reactivity & & & & & \\
\hline 5.3 & $\begin{array}{l}\text { Mechanical Integrity of Ammonia } \\
\text { Decomposition Catalyst }\end{array}$ & & & & & \\
\hline & 5.3.1 Crush Strength & & & & & \\
\hline & 5.3.2 ASTM Attrition Test & & & & & \\
\hline & 5.3.3 Special Attrition Test & & & & & \\
\hline 5.4 & Engineering Model & & & & & \\
\hline
\end{tabular}

Deliverables

a: Catalyst for attrition tests to CPC

b: Draft Final Report

c: Revised Final Report 


\subsection{REFERENCES}

1. Bachovchin, D.M., M.A. Alvin, E.A. Dezubay and P.R. Mulik. 1986. "Study of High Temperature Removal of Alkali in a Pressurized Gasification System." Final Report DOE-MC-20050-2226.

2. Bossart, S.J., D.C. Cicero, C.M. Zeh and R.C. Bedick. 1990. "Gas Stream CleanupTechnology Status Report." DOE/METC-91/0273.

3. Ciliberti, D.F. and T.E. Lippert. 1986. "Performance Evaluation of a Ceramic CrossFlow Filter on a Bench-Scale Coal Gasifier", Westinghouse Eighth Quarterly Report and Monthly Project Status Report for September 1-30. DOE/METC Contract No. DE-AC21-84-MC21338.

4. Crosley, S.M., and R.J. Kedl, 1994. "Laboratory Measurements of Metal Absorption from Simulated Incinerator Flue Gas: Sorbent Selection for Cesium Capture." in Gas Cleaning at High Temperature, ed. R. Clift and J.P.K. Seville, Blackie Academic \& Professional, London, 1994.

5. Eklund, G. R.G. Wetherold, A. Williams, D.P.Maxwell, R.M. Mann and D.B. Burrows. 1994. "Hazardous Air Pollutant Sampling for Advanced Power Systems." Proceedings of the Coal-Fired Power Systems 94 -- Advances in IGCC and PFBC Review Meeting, Vol 2, pp 627-631. DOE/METC-94/1008.

6. Gangwal, S.K., R.P.Gupta, G.N. Krishnan, S.L. Hung. 1994. "NH $\mathrm{H}_{3} \mathrm{H}_{2} \mathrm{~S}$ Advances." in Proceedings of the Coal-Fired Power Systems 93 -- Advances in IGCC and PFBC Review Meeting, DOE/METC-93/6131.

7. Gupta, R.P. 1994. Private communications between Combustion Power Company and Research Triangle Institute.

8. Haas, W.J., D.E. Eckels, S.H. Lee, and R.F. Henry. 1985. "Recent Developments and Observations Pertinent to Real-Time Monitoring of Alkali Concentration in Hot Gas Stream from Fluidized-Bed Combustion of Coal." in Proceedings of Fifth DOE/METC Contractors Review Meeting on Contaminant Control in Coal Derived Gas Streams.

9. Ham, D. A. Gelb, and G. Simmons (1984). "Hot-Gas Chloride Cleanup for Molten Carbonate Fuel Cells." Report No. DOE/MC/16242-1554, Morgantown Technology Center, US Department of Energy, Morgantown, WV.

10. Jain, R.C. and S.C. Young. 1985. "Laboratory/Bench Scale Testing and Evaluation of A.P.T. Dry Plate Scrubber." Air Pollution Technology, Inc. DOE/ET/15492-2030. 
11. Jothimurugesan,K., A.A. Adeyiga, S.K. Gangwal, C. Lewis, A. Bunch. 1993. "Simultaneous Removal of $\mathrm{H}_{2} \mathrm{~S}$ and $\mathrm{NH}_{3}$ in Coal Gasification Processes: Quarterly Report, Sept. 2, 1993-Dec. 31, 1993." Report No. DE94013987.

12. Krishnan, G.N., G.T. Tong, B.J. Wood and N. Korens (1986). "High Temperature Coal Gas Chloride Cleanup for Molten Carbonate Fuel Cell Applications." Report No. DOE/MC/21167, Morgantown Technology Center, US Department of Energy, Morgantown, WV.

132. Krishnan, G.N., B.J. Wood, and J.G. McCarty. 1987. "Study of Ammonia Removal in Coal Gasification Processes." Proceedings of the Seventieth Annual Gasification and Gas Stream Clean-Up Systems Contractors Review Meeting, Morgantown WW.

14. Krishnan, G.N., B.J. Wood, G.T. Tong, and J.G. McCarty. 1988. "Study of Ammonia Removal in Coal Gasification Processes." Report No. DOE/MC/23087-2667, Morgantown Technology Center, US Department of Energy, Morgantown, WV.

15. Krishnan, G.N., B.J. Wood, R.H. Lamoreaux, R.M. Platz and G.P. Smith. 1990. "Determination of the Fate of Alkali Species in Advanced Coal Conversion Systems." Proceedings of the Tenth Annual Gasification and Gas Stream Cleanup Systems Contractors Review Meeting, Vol. 1, pp. 340-351. DOE/METC-90/6115 (DE90009690).

16. Krishnan, G.N., B.J. Wood, A. Canizales, R. Gupta, S.D. Sheluker and R. Ayala (1994). "Development of Disposable Sorbents for Chloride Removal from HighTemperature Coal-Derived Gases." Proceedings of the Coal-Fired Power Systems 94 -- Advances in IGCC and PFBC Review Meeting, Vol 1, pp 478-489. DOE/METC-94/1008, vol.1.

17. Lee, S.D. and I. Johnson. 1980. "Journal of Engineering Power," ASME Trans. 102, pg. 397.

18. Lee, S.D. and K.M. Myles. 1987. "Measurement of Alkali Vapors in PFBC Process Stream and Their Removal With a Fixed Granular-Bed Sorber." In Proceedings of the Seventh Annual Gasification and Gas Stream Cleanup Systems Contractors Review Meeting, Vol. 2, pp. 482-494. DOE/METC-87/6079 (DE87006496).

19. Lee, S.D., F.G. Teats, W.M. Swift and D.D. Banerjee. 1993. "Measurement of Alkali-Vapor Emission from Pressurized Fluidized-Bed Combustion of Illinois Coal." 12th International Conference on Fluidized Bed Combustion, San Diego, CA

20. Leppälahti, J., P. Simell and E. Kurkela. 1991. "Catalytic Conversion of Nitrogen Compounds in Gasification Gas." Fuel Processing Technology, 29, pp 43-56. 
21. Liang, D.T., E.J. Anthony, B.K. Loewen and D.J. Yates. 1991. "Halogen Capture by Limestone During Fluidized-Bed Combustion." In Proceedings of the 11th International Conference on Fluidized Bed Combustion, Vol. 2, pp. 917-922.

22. McLaughlin, J. 1990. "The Removal of Volatile Alkali Salt Vapors from Hot CoalDerived Gases". PhD Thesis, Guildford, UK, Dept. of Chemical and Process Engineering, University of Surrey, 214 pp.

23. Mojtahedi, W. and R. Blackman. 1989a. "Release of Alkali Metals in Pressurized Fluidized-Bed Combustion and Gasification of Peat." Public Technical Research Center, Finland, 53, March, $48 \mathrm{pp}$.

24. Mojtahedi, W. U. Mroueh, 1989b "Trace Elements Removal from Hot Flue Gases." Technical Research Center of Finland, Research Reports 663.

25. Mojtahedi, M., M. Nieminen, S. Hulkkonen, and A. Jahkola. 1990. "Partitioning of Trace Elements in Pressurized Fluidized-Bed Combustion." Fuel Processing Technology, 26 pp. 83-97.

26. Mudd, M.J. and P.A. Del Portal 1994. "HAPS Sampling at Tidd PFBC." Proceedings of the Coal-Fired Power Systems 94 -- Advances in IGCC and PFBC Review Meeting, Vol 2, pp 607-615. DOE/METC-94/1008.

Mulik, P.K., M.A. Alvin, and D.M. Bachorchin. 1983. Simultaneous Pressurized Gasification System." Program Report DOE/METC16372-8. Westinghouse Research and Development Center, Pittsburgh, PA.

27. O'Brien, W.S. and R.P. Gupta. "Desulfurization of Hot Fuel Gas Produced From High-Chlorine Illinois Coals." Final Report to Center for Research on Sulfur in Coal.

28. Peukert, W. and F. Loffler. 1993. "Sorption of $\mathrm{SO}_{2}$ and $\mathrm{HCl}$ in Granular Bed Filters." Gas Cleaning at High Temperatures, R. Clift and J.P.K. Seville (Editors), pp. 604623.

29. Pigeaud, A.E. and J.J. Helble. 1994. Proceedings of the Coal-Fired Power Systems 94 -- Advances in IGCC and PFBC Review Meeting, Vol 2, pp 616-626. DOE/METC-94/1008.

Schultz, R.A. 1994. Private Communications with R.P. Gupta

30. Sloss, Lesley L. 1992. "Halogens Emissions from Coal Combustion." IEA Coal Research Report IEACR/45.

31. Tamhankar, S.S. and C.Y. Wen. 1981. "Review of In-Bed Hydrocarbon, Alkali and 
Trace Metals Control in Coal Conversion Processes." West Virginia University. DOE Report DE83006376.

32. Uberoi, M. 1990. "High-Temperature Removal of Metal Vapors by Solid Sorbents." PhD Thesis, University of Arizona.

33 Removal from Flue Gases by Solid Sorbents." Prog. Energy Combustion Science, Vol. 16 , No. 4, pp. 205-211.

34. Uberoi, M. and F. Shadman. 1991a. "High-Temperature Removal of Cadmium Compounds Using Solid Sorbents." Environmental Science Technology, Vol. 25, No. 7 , pp. 1285-1289.

35. Uberoi, M. and F. Shadman. 1991b. "Fundamentals of Heavy Metal Removal by Dry Sorbents." Prepr. Pap. Am. Chem. Soc., Div. Fuel Chem., Vol. 36, No. 4, pp. 1724-1729.

36. Wilson, K.B. and J.C. Haas. 1989. "Performance Analysis of a Screenless (CounterCurrent) Granular Bed Filter on a Subpilot-Scale PFBC," Final Report. U.S. Dept. of Energy, DOE/MC/21335.

37. Zakkay, V., J. McClung, P. Radhakrishnan, S. Panunzio, K. Sillakumar and A. Ganeish. 1985. "Gas and Alkali Emission from Pressurized Fluidized-Bed Combustion of Lignite." In Proceedings of the Eighth International Conference on Fluidized-Bed Combustion, Vol. 3, pp. 1186-1196. 